\title{
ॠUSES
}

X

National Water-Quality Assessment Program

\section{Environmental Settings of the South Fork lowa River Basin, lowa, and the Bogue Phalia Basin, Mississippi, 2006-10}

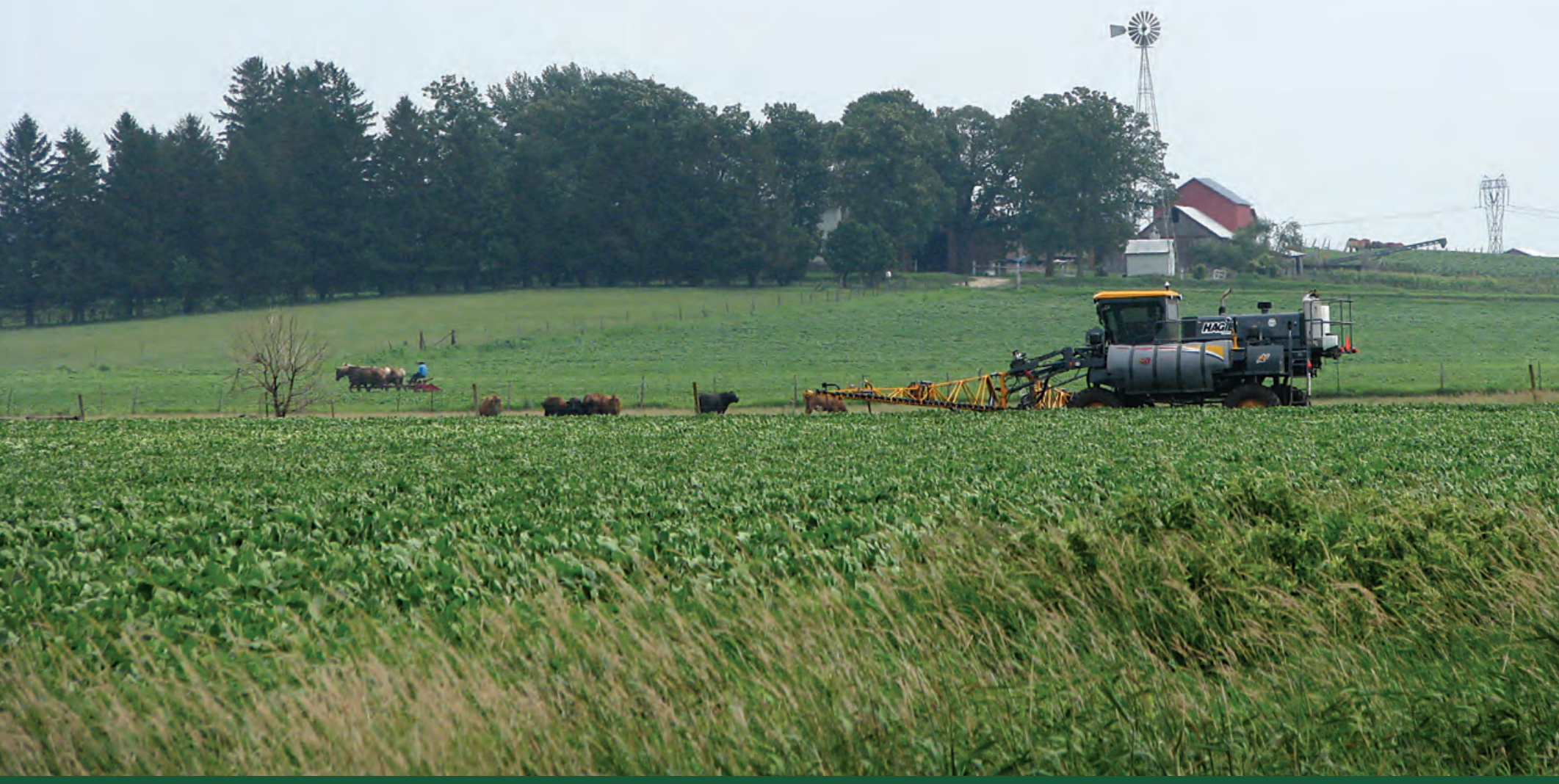

Scientific Investigations Report 2012-5021

U.S. Department of the Interior

U.S. Geological Survey 
Cover: Photograph showing contrasting weed control methods in lowa, 2010.

Photograph by Shannon Stubbs, U.S. Geological Survey, lowa City, lowa. 


\section{Environmental Settings of the South Fork lowa River Basin, lowa, and the Bogue Phalia Basin, Mississippi, 2006-10}

By Kathleen A. McCarthy, Claire E. Rose, and Stephen J. Kalkhoff

National Water-Quality Assessment Program

Scientific Investigations Report 2012-5021 


\title{
U.S. Department of the Interior \\ KEN SALAZAR, Secretary \\ U.S. Geological Survey \\ Marcia K. McNutt, Director
}

\author{
U.S. Geological Survey, Reston, Virginia: 2012
}

For more information on the USGS - the Federal source for science about the Earth, its natural and living resources, natural hazards, and the environment, visit http://www.usgs.gov or call 1-888-ASK-USGS.

For an overview of USGS information products, including maps, imagery, and publications, visit http://www.usgs.gov/pubprod

To order this and other USGS information products, visit http://store.usgs.gov

Any use of trade, product, or firm names is for descriptive purposes only and does not imply endorsement by the U.S. Government.

Although this report is in the public domain, permission must be secured from the individual copyright owners to reproduce any copyrighted materials contained within this report.

Suggested citation:

McCarthy, K.A., Rose, C.E., and Kalkhoff, S.J., 2012, Environmental settings of the South Fork lowa River basin, lowa, and the Bogue Phalia basin, Mississippi, 2006-10: U.S. Geological Survey Scientific Investigations Report 2012-5021, $22 \mathrm{p}$. 


\section{Foreword}

The U.S. Geological Survey (USGS) is committed to providing the Nation with reliable scientific information that helps to enhance and protect the overall quality of life and that facilitates effective management of water, biological, energy, and mineral resources (http://www.usgs.gov/). Information on the Nation's water resources is critical to ensuring long-term availability of water that is safe for drinking and recreation and is suitable for industry, irrigation, and fish and wildlife. Population growth and increasing demands for water make the availability of that water, measured in terms of quantity and quality, even more essential to the long-term sustainability of our communities and ecosystems.

The USGS implemented the National Water-Quality Assessment (NAWQA) Program in 1991 to support national, regional, State, and local information needs and decisions related to water-quality management and policy (http://water.usgs.gov/nawqa). The NAWQA Program is designed to answer: What is the quality of our Nation's streams and groundwater? How are conditions changing over time? How do natural features and human activities affect the quality of streams and groundwater, and where are those effects most pronounced? By combining information on water chemistry, physical characteristics, stream habitat, and aquatic life, the NAWQA Program aims to provide science-based insights for current and emerging water issues and priorities. From 1991 to 2001, the NAWQA Program completed interdisciplinary assessments and established a baseline understanding of water-quality conditions in 51 of the Nation's river basins and aquifers, referred to as Study Units (http://water.usgs.gov/nawqa/studies/study units.html).

National and regional assessments are ongoing in the second decade (2001-2012) of the NAWQA Program as 42 of the 51 Study Units are selectively reassessed. These assessments extend the findings in the Study Units by determining water-quality status and trends at sites that have been consistently monitored for more than a decade, and filling critical gaps in characterizing the quality of surface water and groundwater. For example, increased emphasis has been placed on assessing the quality of source water and finished water associated with many of the Nation's largest community water systems. During the second decade, NAWQA is addressing five national priority topics that build an understanding of how natural features and human activities affect water quality, and establish links between sources of contaminants, the transport of those contaminants through the hydrologic system, and the potential effects of contaminants on humans and aquatic ecosystems. Included are studies on the fate of agricultural chemicals, effects of urbanization on stream ecosystems, bioaccumulation of mercury in stream ecosystems, effects of nutrient enrichment on aquatic ecosystems, and transport of contaminants to public-supply wells. In addition, national syntheses of information on pesticides, volatile organic compounds (VOCs), nutrients, trace elements, and aquatic ecology are continuing.

The USGS aims to disseminate credible, timely, and relevant science information to address practical and effective water-resource management and strategies that protect and restore water quality. We hope this NAWQA publication will provide you with insights and information to meet your needs and will foster increased citizen awareness and involvement in the protection and restoration of our Nation's waters.

The USGS recognizes that a national assessment by a single program cannot address all water-resource issues of interest. External coordination at all levels is critical for cost-effective management, regulation, and conservation of our Nation's water resources. The NAWQA Program, therefore, depends on advice and information from other agencies—Federal, State, regional, interstate, Tribal, and local—as well as nongovernmental organizations, industry, academia, and other stakeholder groups. Your assistance and suggestions are greatly appreciated. 
This page intentionally left blank. 


\section{Contents}

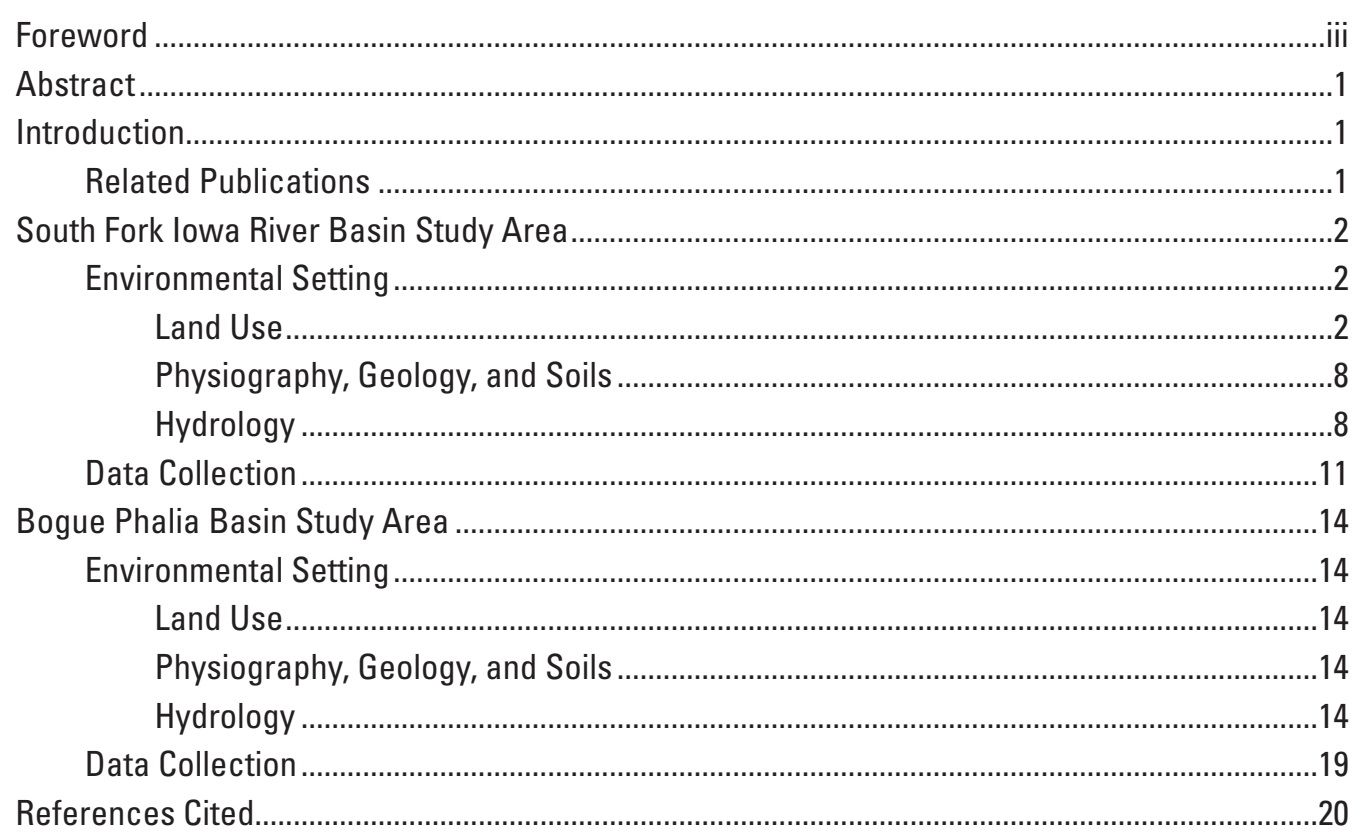




\section{Figures}

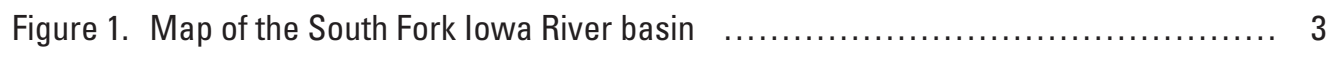

Figure 2. Map showing locations of data-collection sites in the South Fork lowa River

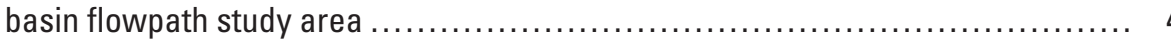

Figure 3. Map showing locations of streambed data-collection sites in the South Fork

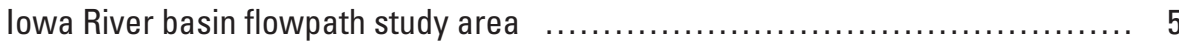

Figure 4. Map showing locations of data-collection sites and drainage features in the South Fork lowa River basin headwaters catchment

Figure 5. Map showing locations of data-collection sites in the flowpath study area of the South Fork lowa River basin headwaters catchment

Figure 6. Graph showing mean monthly precipitation at the lowa atmospheric sampling sites

Figure 7. Map showing location of the South Fork lowa River basin in relation to the Des Moines Lobe in lowa

Figure 8. Map showing thickness of unconsolidated material and the location of alluvial deposits in the South Fork lowa River basin

Figure 9. Map showing streambed temperatures near the outflow from the South Fork

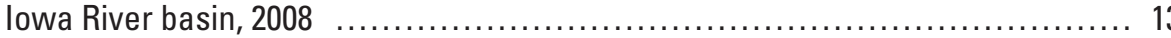

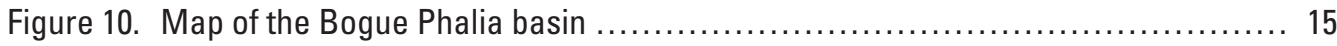

Figure 11. Map showing locations of data-collection sites in the Bogue Phalia basin, headwaters focused study area, and basin outlet focused study area

Figure 12. Graph showing mean monthly precipitation at the Mississippi atmospheric sampling sites

\section{Tables}

Table 1. Data collection sites in the South Fork lowa River basin, water years 2006-09 . . 22

Table 2. Data collection sites in the Bogue Phalia basin, water years $2006-10 \ldots \ldots \ldots \ldots 22$ 


\title{
Conversion Factors and Datums
}

\author{
Conversion Factors
}

\begin{tabular}{lll}
\hline \multicolumn{1}{c}{ Multiply } & By & \multicolumn{1}{c}{ To obtain } \\
\hline centimeter $(\mathrm{cm})$ & Length & \\
millimeter $(\mathrm{mm})$ & 0.3937 & inch (in.) \\
meter $(\mathrm{m})$ & 0.03937 & inch (in.) \\
kilometer $(\mathrm{km})$ & 3.281 & foot (ft) \\
kilometer $(\mathrm{km})$ & 0.6214 & mile (mi) \\
meter $(\mathrm{m})$ & 0.5400 & mile, nautical (nmi) \\
\hline & 1.094 & yard (yd) \\
\hline square meter $\left(\mathrm{m}^{2}\right)$ & Area & \\
hectare $(\mathrm{ha})$ & 0.0002471 & acre \\
square hectometer $\left(\mathrm{hm}^{2}\right)$ & 2.471 & acre \\
square kilometer $\left(\mathrm{km}^{2}\right)$ & 2.471 & acre \\
square meter $\left(\mathrm{m}^{2}\right)$ & 247.1 & acre \\
square kilometer $\left(\mathrm{km}^{2}\right)$ & 10.76 & square foot (ft $\left.{ }^{2}\right)$ \\
\hline & 0.3861 & square mile (mi $\left.{ }^{2}\right)$ \\
\hline cubic meter $\left(\mathrm{m}^{3}\right)$ & Volume & \\
cubic decimeter $\left(\mathrm{dm}^{3}\right)$ & 264.2 & gallon (gal) \\
cubic meter $\left(\mathrm{m}^{3}\right)$ & 0.2642 & gallon (gal) \\
cubic centimeter $\left(\mathrm{cm}^{3}\right)$ & 0.0002642 & million gallons (Mgal) \\
\hline & 0.06102 & cubic inch (in $\left.{ }^{3}\right)$ \\
\hline cubic meter per second $\left(\mathrm{m}^{3} / \mathrm{s}\right)$ & Flow rate & \\
\hline
\end{tabular}

Temperature in degrees Celsius $\left({ }^{\circ} \mathrm{C}\right)$ may be converted to degrees Fahrenheit $\left({ }^{\circ} \mathrm{F}\right)$ as follows:

$$
{ }^{\circ} \mathrm{F}=\left(1.8 \times{ }^{\circ} \mathrm{C}\right)+32 \text {. }
$$

Temperature in degrees Fahrenheit $\left({ }^{\circ} \mathrm{F}\right)$ may be converted to degrees Celsius $\left({ }^{\circ} \mathrm{C}\right)$ as follows:

$$
{ }^{\circ} \mathrm{C}=\left({ }^{\circ} \mathrm{F}-32\right) / 1.8 \text {. }
$$

Datums

Vertical coordinate information is referenced to the North American Vertical Datum of 1988 (NAVD 88).

Horizontal coordinate information is referenced to the North American Datum of 1983 (NAD 83).

Altitude, as used in this report, refers to distance above the vertical datum. 
This page intentionally left blank. 


\title{
Environmental Settings of the South Fork lowa River Basin, lowa, and the Bogue Phalia Basin, Mississippi, 2006-10
}

\author{
By Kathleen A. McCarthy, Claire E. Rose, and Stephen J. Kalkhoff
}

\begin{abstract}
Studies of the transport and fate of agricultural chemicals in different environmental settings were conducted by the U.S. Geological Survey (USGS) National Water-Quality Assessment (NAWQA) Program's Agricultural Chemicals Team (ACT) at seven sites across the Nation, including the South Fork Iowa River basin in central Iowa and the Bogue Phalia basin in northwestern Mississippi. The South Fork Iowa River basin is representative of midwestern agriculture, where corn and soybeans are the predominant crops and a large percentage of the cultivated land is underlain by artificial drainage. The Bogue Phalia basin is representative of corn, soybean, cotton, and rice cropping in the humid, subtropical southeastern United States. Details of the environmental settings of these basins and the data-collection activities conducted by the USGS ACT over the 2006-10 study period are described in this report.
\end{abstract}

\section{Introduction}

The South Fork Iowa River basin in central Iowa and the Bogue Phalia basin in northwestern Mississippi are two of seven basins selected for study by the U.S. Geological Survey (USGS) National Water-Quality Assessment (NAWQA) Program's Agricultural Chemicals Team (ACT) (Capel and others, 2008). The goal of the ACT studies was to identify and understand the natural and human factors that affect the transport and fate of agricultural chemicals in different environmental settings across the Nation.

This report provides information on the environmental settings of the South Fork Iowa River and Bogue Phalia basins.

\section{Related Publications}

Prior to the ACT studies, the NAWQA program conducted water-quality studies in eastern Iowa river basins, including the South Fork Iowa River basin. Results from this earlier work are available in Becher and others (2001), Porter and others (2001), Kalkhoff and others (2001, 2003), and Schnoebelen and others (2003).

Previous NAWQA work in the Mississippi Embayment, including the Bogue Phalia basin, has addressed pesticides (Coupe and others, 1998, 2005; Coupe, 2000) and nutrients (Coupe, 2002; Runner and others, 2002) in surface water, as well as pesticides in the atmosphere (Coupe and others, 2000; Foreman and others, 2000). Water-quality investigations in the Mississippi Embayment are summarized by Kleiss and others (2000). Currently available results from the ACT study in the Bogue Phalia basin include an estimate of streambed fluxes during extreme hydrologic events (Barlow and Coupe, 2009), a characterization of the transport and fate of the herbicide fluometuron in surface water (Coupe, 2007), and a study of the factors that control the transport of nitrate to shallow groundwater (Welch and others, 2011).

Results from data collection at all seven ACT study areas, including the South Fork Iowa River and Bogue Phalia basins, are available in McCarthy and others (2011). A full bibliography of publications resulting from NAWQA work, including the seven ACT studies, is available in U.S. Geological Survey (2011). 


\section{South Fork lowa River Basin Study Area}

In the South Fork Iowa River basin (fig. 1), data for the ACT study were collected during water years 2006-09 for surface water, groundwater, overland flow, the unsaturated zone, subsurface drain systems, the atmosphere, and the streambed (table 1). To understand the basin as a whole, surface-water data were collected at the outflow from the South Fork Iowa River basin (site 05451210, fig. 1) to measure flow, major ions, carbon, nutrients, sediment, and pesticides leaving the study area. This site also has been sampled as part of the NAWQA status and trends network and has continuous stream discharge and periodic nutrient, sediment, and pesticide data from samples collected since 1996 (U.S. Geological Survey, 2001, 2008, 2009). Groundwater data also were collected at a number of shallow (water table) wells near site 05451210 (fig. 2).

Surface-water data also were collected at the outflows from two catchments nested within the basin: site 05451080 at the outflow from the headwaters catchment of the South Fork Iowa River near Blairsburg, and site 05451070 at the confluence of three large public subsurface drains that form the origin of the South Fork Iowa River (fig. 1).

Additional data were collected from the unsaturated zone and groundwater (fig. 2) and from the streambed (fig. 3) for focused studies near site 05451210 . These focused studies were designed to investigate the transport of agricultural chemicals through a shallow alluvial aquifer toward the stream and between the shallow aquifer and the stream through the streambed.

At a third focus study area in the headwaters catchment (figs. 4-5), data were collected from the atmosphere, overland flow, subsurface drains, the unsaturated zone, and groundwater to investigate the movement of water and agricultural chemicals through the soil to the water table and through shallow groundwater to the subsurface drain system and eventually to the South Fork Iowa River.

Precipitation data and other weather parameters were collected near the basin outlet (site WT6, fig. 2); precipitation data, other weather parameters, and air-quality data were collected in the headwaters catchment (site PPT-1, fig. 4).

\section{Environmental Setting}

The South Fork Iowa River study basin covers $570 \mathrm{~km}^{2}$ in central Iowa, upstream of site 5451210 on the South Fork Iowa River (fig. 1); flow at site 05451210 includes drainage from Tipton Creek. The central area of Iowa has moderate temperatures ranging from a monthly mean of $23.4^{\circ} \mathrm{C}$ in July to a monthly mean of $-7.7^{\circ} \mathrm{C}$ in January. Mean annual precipitation in central Iowa during the past
118 years averaged $83 \mathrm{~cm}$ (National Oceanic and Atmospheric Administration, 2002b). However, annual rainfall amounts during the study in $2007(114 \mathrm{~cm})$ and 2008 (124 cm) were the fourth and second greatest, respectively, on record. Monthly precipitation increases in early spring after snowmelt from less than $5.0 \mathrm{~cm}$ in February to more than $12 \mathrm{~cm}$ in June (fig. 6). Rain is considered reliable in spring, but decreases throughout the summer. Occasionally, heavy spring rains can delay crop planting. The smallest amount of precipitation occurs during December, January, and February. Evapotranspiration plays a large role in the water budget of the region.

The South Fork Iowa River originates at the confluence of three large public subsurface drains (site 05451070, fig. 1) in Hamilton County, about $2.5 \mathrm{~km}$ north of Blairsburg, Iowa. The South Fork flows northeast from the origin for about $7.0 \mathrm{~km}$ before flowing in a generally southeasterly direction through Hardin County where it joins the Iowa River near site 05451210, south of Eldora, Iowa (fig. 1). The natural channel of the South Fork Iowa River was extended from western Hardin County to its current origin in eastern Hamilton County with the construction of an artificial drainage ditch in the early 1900s. The ditch was dug to create additional farmland by draining wetlands and potholes. Numerous other drainage ditches join the South Fork Iowa River in the upper half of the watershed.

\section{Land Use}

More than 95 percent of the South Fork Iowa River basin is used for agriculture (Tomer and others, 2008b), and more than 85 percent of the agricultural land is used for the production of corn and soybeans (Tomer and others, 2008a). Historically, crops grown in the basin were split nearly equally between corn and soybeans. However, because of the demand for corn-based ethanol, the number or acres used for corn production increased substantially in 2007 (U.S. Department of Agriculture, 2009), and the number of acres used for soybean production decreased proportionally. A broad variety of fertilizers, herbicides, and insecticides are used to enhance production and protect crops. In addition to row crop agriculture, large numbers of confined feeding operations (CAFOs) (Tomer and others, 2008a) are present in the basin. Manure generated from the CAFOs is a major source of nutrients applied in the basin.

The South Fork Iowa River basin is sparsely populated. Most of the population lives in rural areas and in three small communities of less than 500 residents. Less than 8,000 people live in the South Fork Iowa River basin (U.S. Census Bureau, 2000a, 2000b). Water for domestic and animal use is almost entirely from ground water. The amount of water used for farm animals probably is several times greater than the amount used for domestic purposes in the basin. 

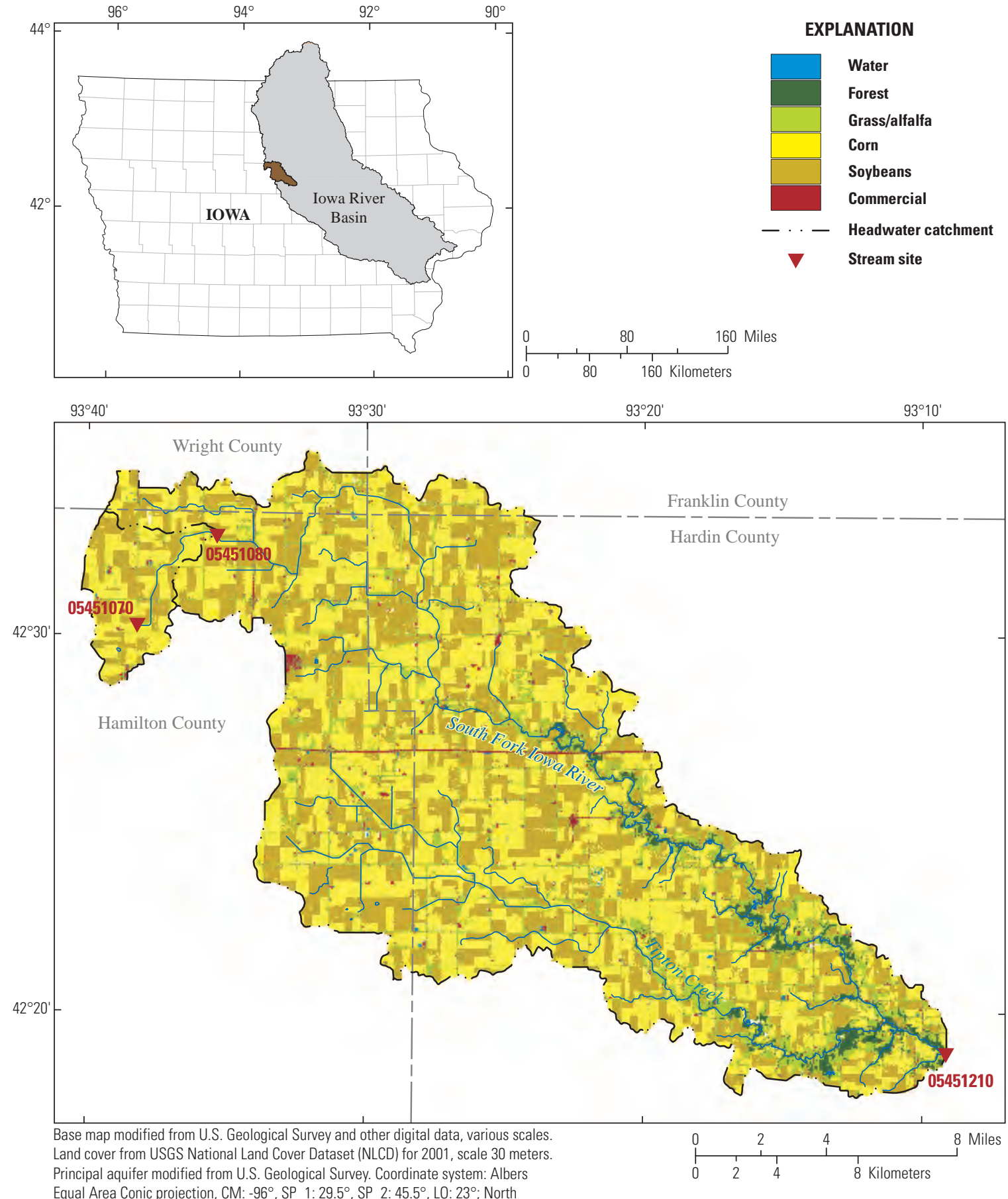

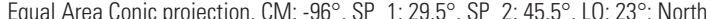
American Datum of 1983.

Figure 1. South Fork lowa River basin. 

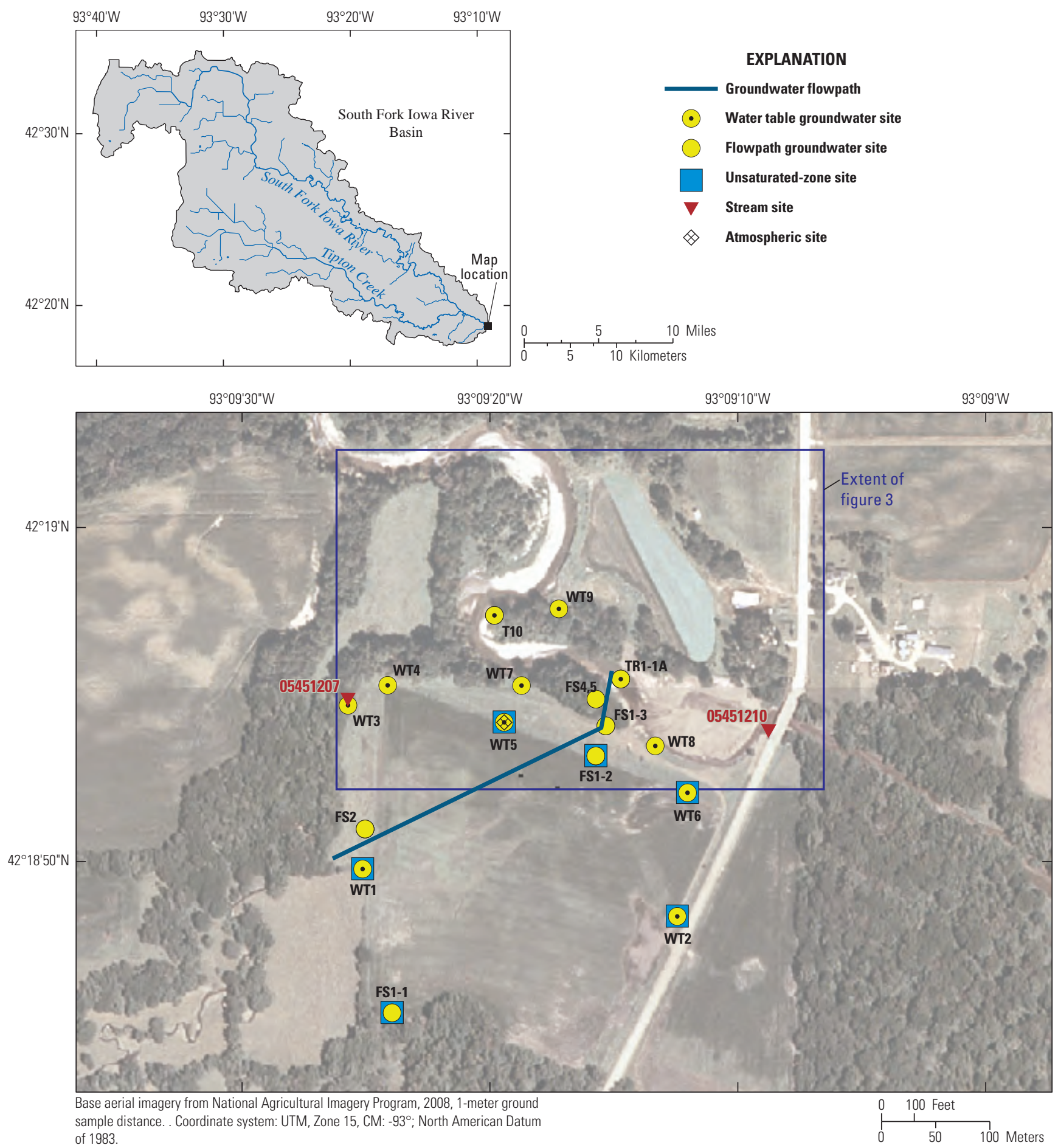

Figure 2. Locations of data-collection sites in the South Fork lowa River basin flowpath study area. 

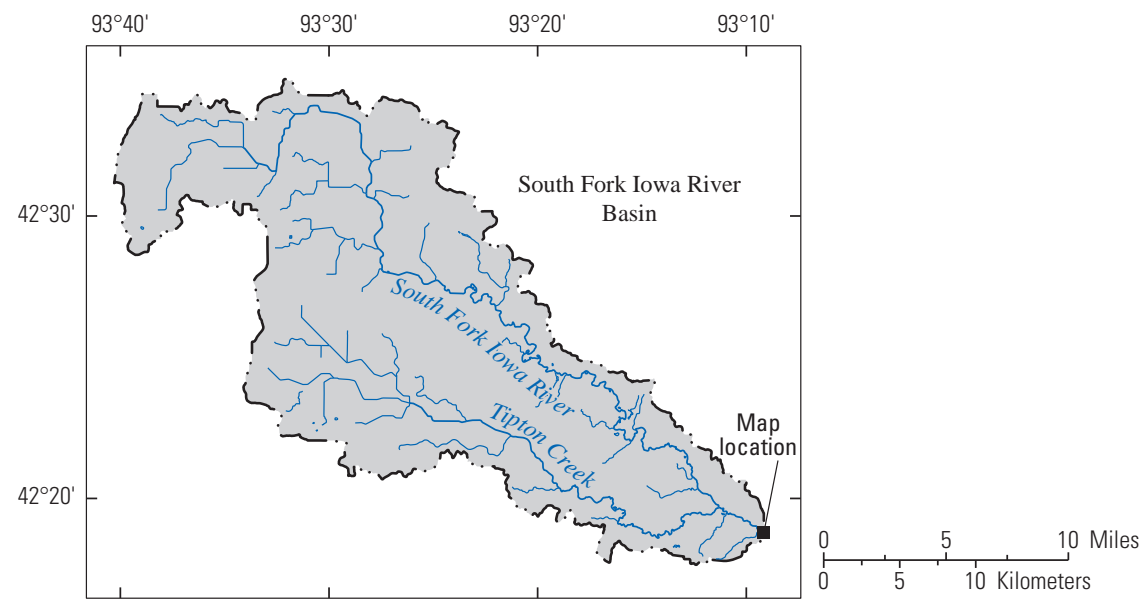

\section{EXPLANATION}

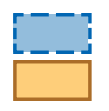

Streambed 2007

Streambed 2008

- . B - Basin boundary

Streambed site

$\nabla \quad$ Stream site

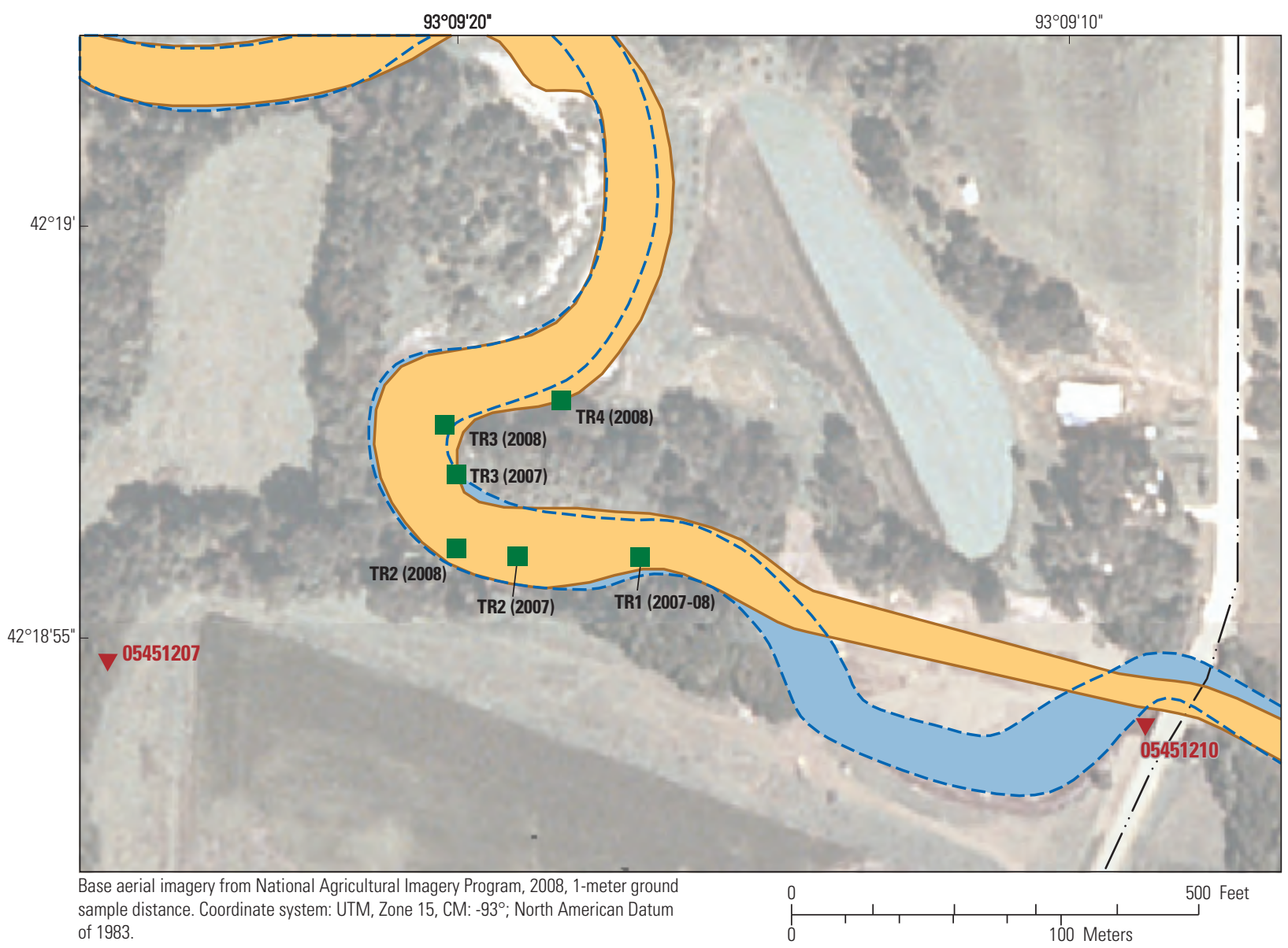

Figure 3. Locations of streambed data-collection sites in the South Fork lowa River basin flowpath study area. 

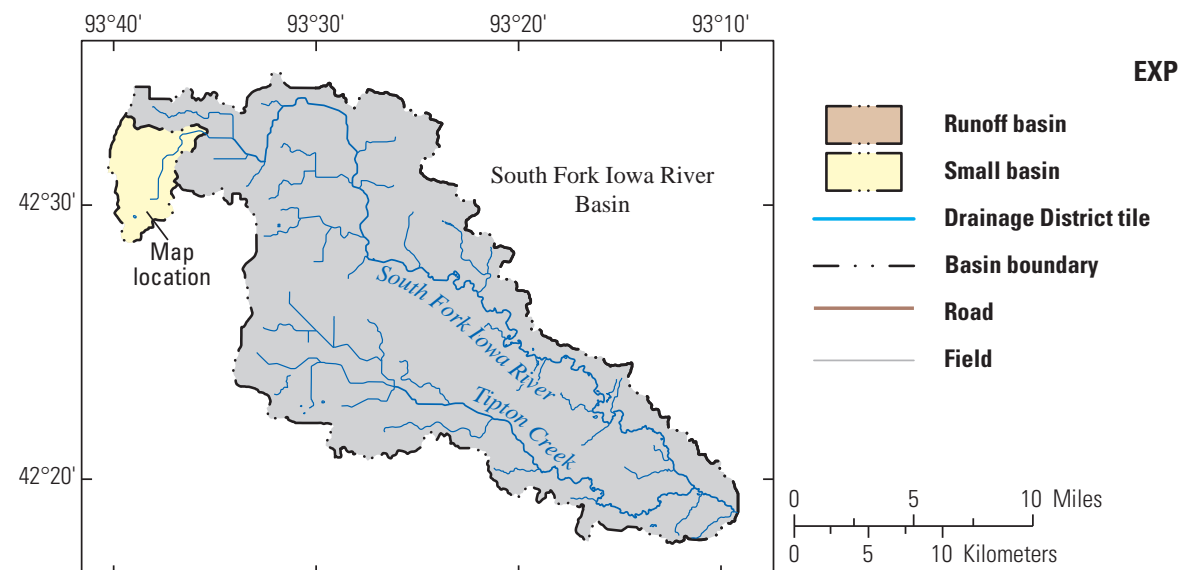

EXPLANATION
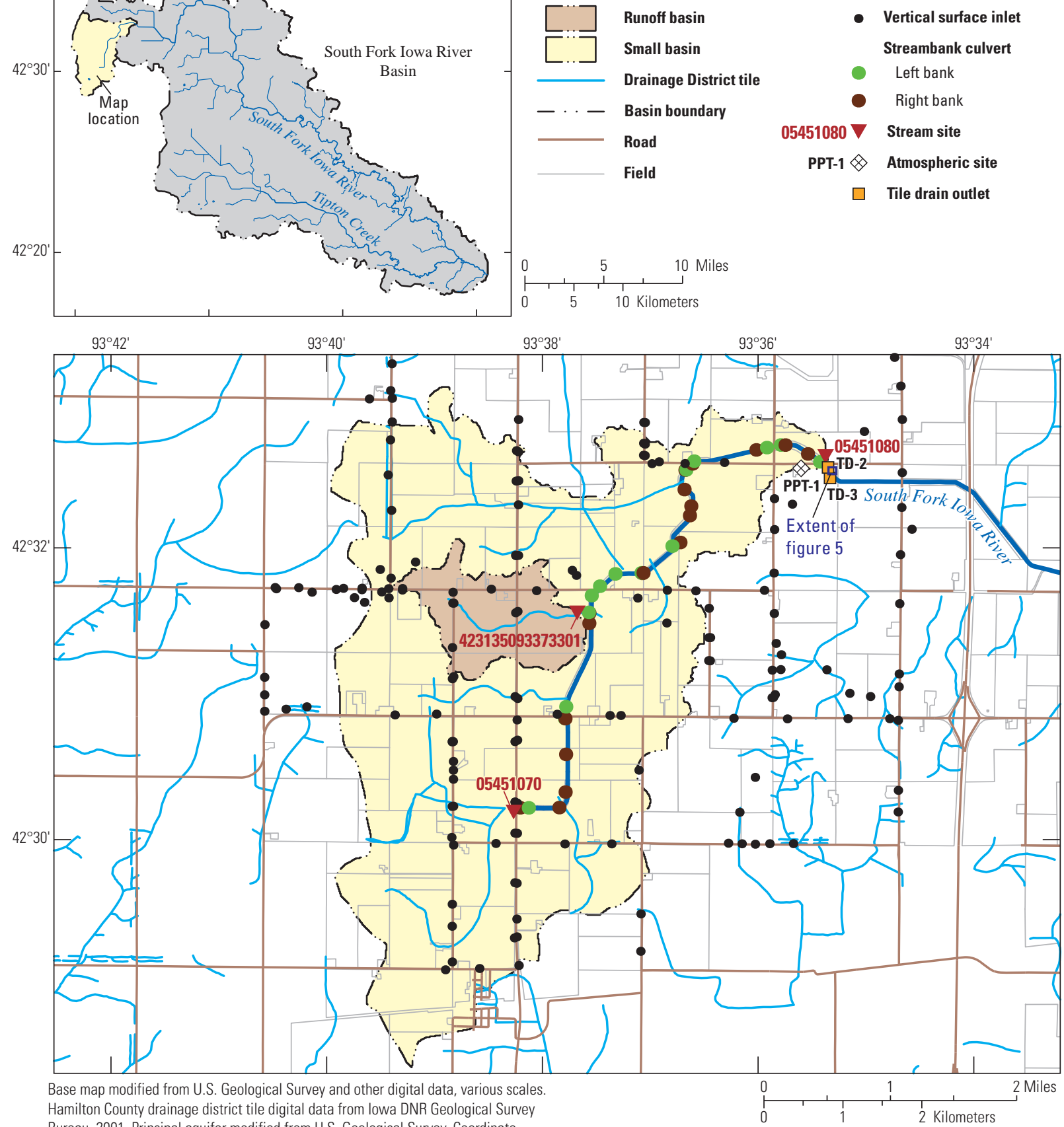

Bureau, 2001. Principal aquifer modified from US. Geological Survey Coordinate

system: UTM, Zone 15, CM: -93; North American Datum of 1983. Spatial accuracy

based on standards for USGS 1:24,000-scale maps; positional accuracy estimated to be

no better than 75 meters.

Figure 4. Locations of data-collection sites and drainage features in the South Fork lowa River basin headwaters catchment. 


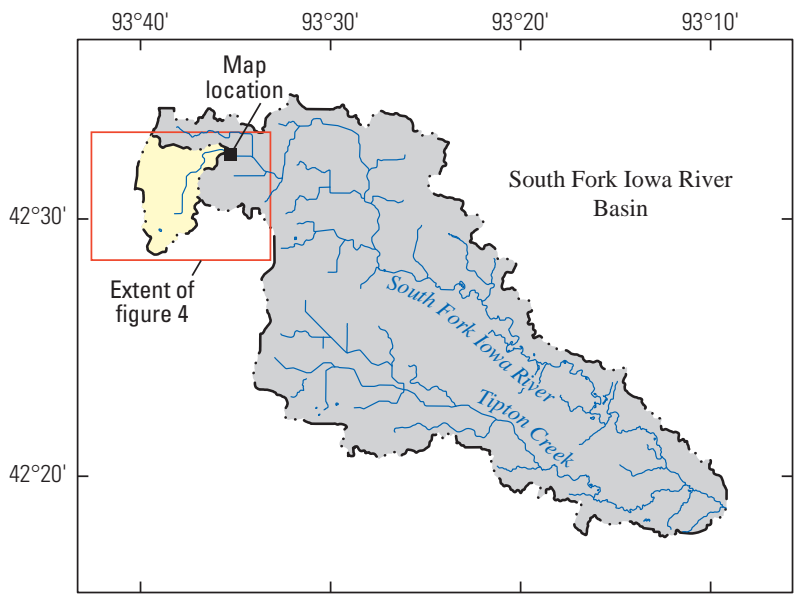

\section{EXPLANATION}

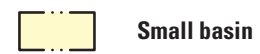

Stream

Drainage District tile

Field

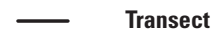

Flowpath groundwater site

$\square \quad$ Unsaturated-zone site

$\square \quad$ Tile outlet

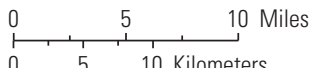

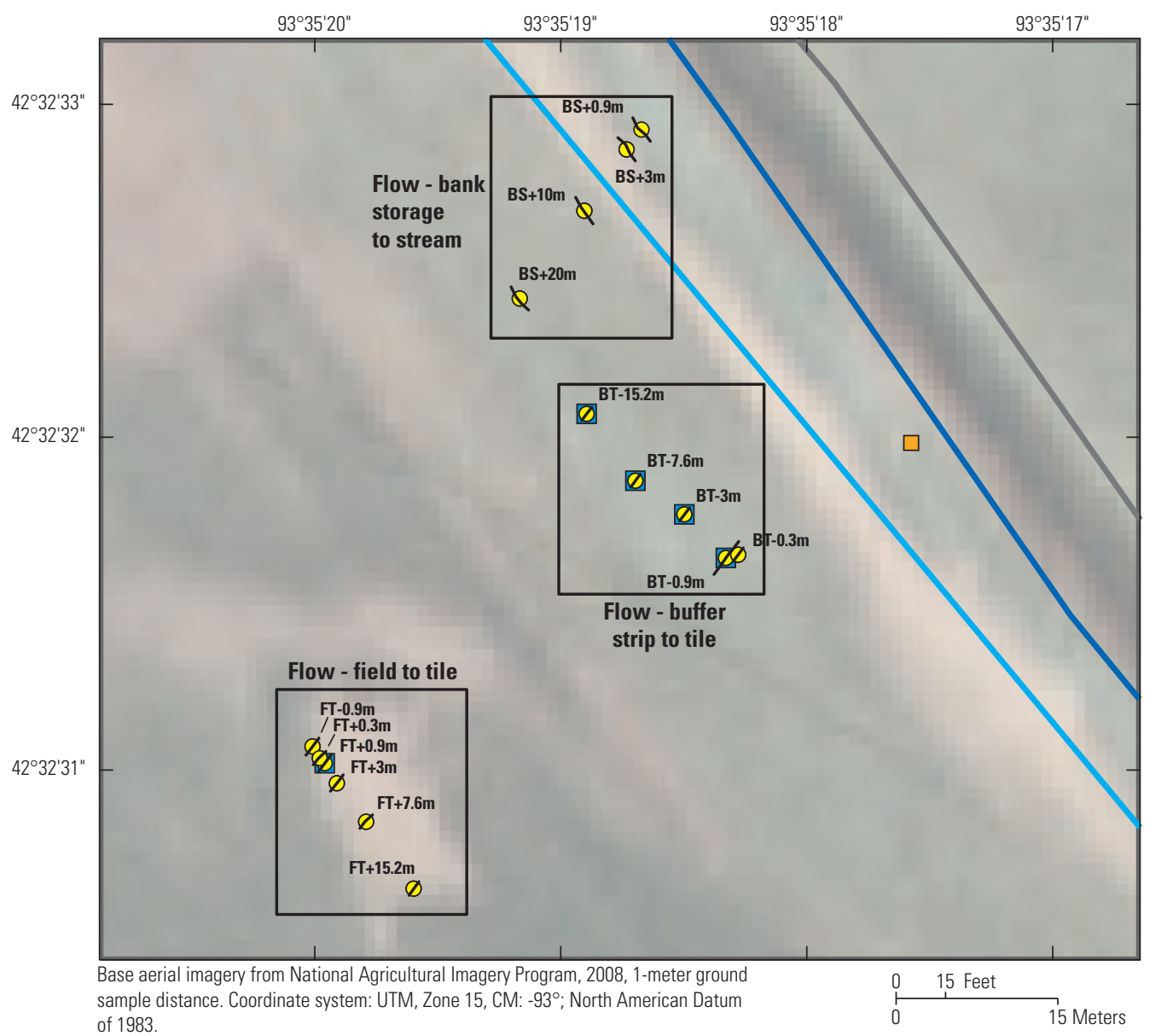

Figure 5. Locations of data-collection sites in the flowpath study area of the South Fork lowa River basin headwaters catchment. 


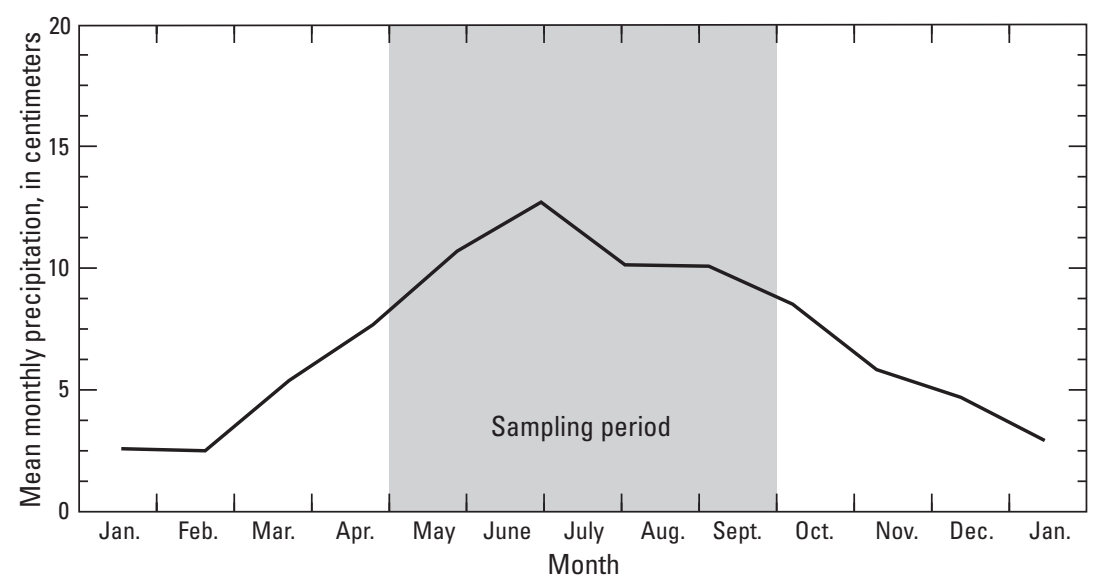

Figure 6. Mean monthly precipitation at the lowa atmospheric sampling sites. Data are from National Oceanic and Atmospheric Administration (2002b) 1931-2000 average for lowa climatic region 5 .

\section{Physiography, Geology, and Soils}

Physiographically, the South Fork Iowa River basin is completely contained within the Des Moines Lobe, an area that was glaciated, leaving behind a till plain, lateral moraines, and major glacial drainageways (fig. 7; Quade and others, 2000; Quade and Giglierona, 2006). Glacial and fluvial deposits that range from 20 to more than $75 \mathrm{~m}$ in thickness overlie Mississippian limestone and dolomite bedrock formations (ig. 8). Glacial deposits primarily consist of till with interbedded sand and gravel lenses. Sand and gravel eroded from the glacial deposits by streams are located adjacent to the South Fork and its tributaries in the lower portion of the basin.

Soils were developed under long-grass prairies on the glacial till deposits and are highly productive. Soils generally grade from well-drained oxic soils on the hills and ridgetops to somewhat poorly to poorly drained soils on the side slopes. Depressions in the landscape have hypoxic, poorly drained soils that developed under prairie potholes and wetlands. Drainage has been improved in large parts of the basin by installation of subsurface drains and open surface ditches (Tomer and others, 2008b). Available water capacity of the soil is high, and organic matter content is high to moderate. These soils are well suited to row crops, such as corn and soybeans.

Unconsolidated and bedrock aquifers underlie the South Fork Iowa River basin. Unconsolidated aquifers consist of fluvial sand and gravel deposits located adjacent to the natural channels of the streams and glacial deposits of sand and gravel found scattered throughout the till. Unconsolidated aquifers are a minor source of water for domestic and agricultural supplies. Sandstone bedrock units of the Mississippian aquifer system that underlies from 15 to more than $30 \mathrm{~m}$ of unconsolidated material (Olcott, 1992) is the major source of water for domestic and agricultural purposes.

\section{Hydrology}

Much of the flow in the South Fork Iowa River originates from subsurface agricultural drain flow. During extreme events, when rainfall exceeds the infiltration capacity of the soil, most water at the origin of the South Fork Iowa River (site 5451070, fig. 1) probably originates from runoff to surface ditches and the surface inlets of subsurface drain networks. Downstream at site 05451080 (fig. 1), the average annual discharge (2006-08) of about $0.5 \mathrm{~m}^{3} / \mathrm{s}$ primarily is from subsurface drains. At the basin outflow (site 05451210, fig. 1), the average annual discharge is about $5.2 \mathrm{~m}^{3} / \mathrm{s}$.

In the upper basin, at both sites 05451070 and 05451080 , the South Fork Iowa River has periods of low flow. At base flow, water contributing to flow at site 05451080 originates primarily from subsurface drain discharge with little or no groundwater seepage directly into the man-made channel. In contrast, discharge during base-flow conditions at site 5451210 is a combination of inflow from subsurface drains and from groundwater seepage directly into the river where coarse-grained, alluvial deposits are present adjacent to the river.

Major modifications have been made to the natural hydrology of the South Fork Iowa River basin in support of agriculture. A network of surface drainage ditches were dug and subsurface drains were installed in the early part of the 1900s to facilitate the drainage of extensive wetland areas to allow production of crops. Installation of subsurface drains has continued to the present (2011). In many areas, excavated materials were deposited as berms adjacent to ditches. A berm commonly dams surface runoff directly into the ditch, and culverts typically were installed through the berms and ditch banks to allow runoff to flow into the ditch. The enhanced drainage permits better timing of seasonal cultivation, lowers the cost of cultivation, and improves seed germination. 

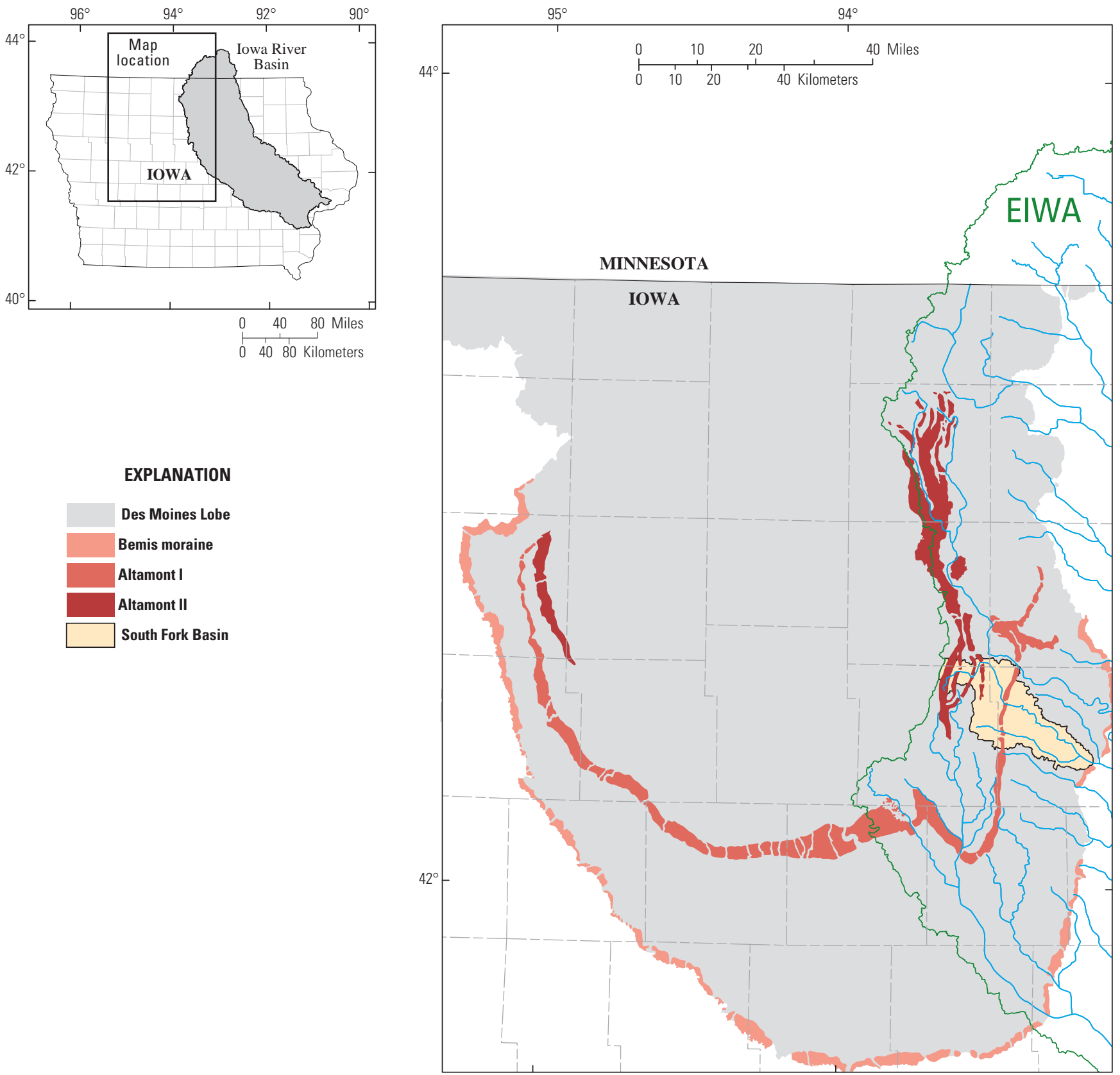

Base map modified from U.S. Geological Survey and other digital data, various scales. Des Moines Lake and its glacial advances in lowa digital dataset from lowa DNR Geological Survey Bureau, 1995. Principal aquifer modified from U.S. Geological Survey. Coordinate system: UTM, Zone 15, CM: -93; North American Datum of 1983.

Figure 7. Location of the South Fork lowa River basin in relation to the Des Moines Lobe in lowa. Selected terminal moraines also are shown. 


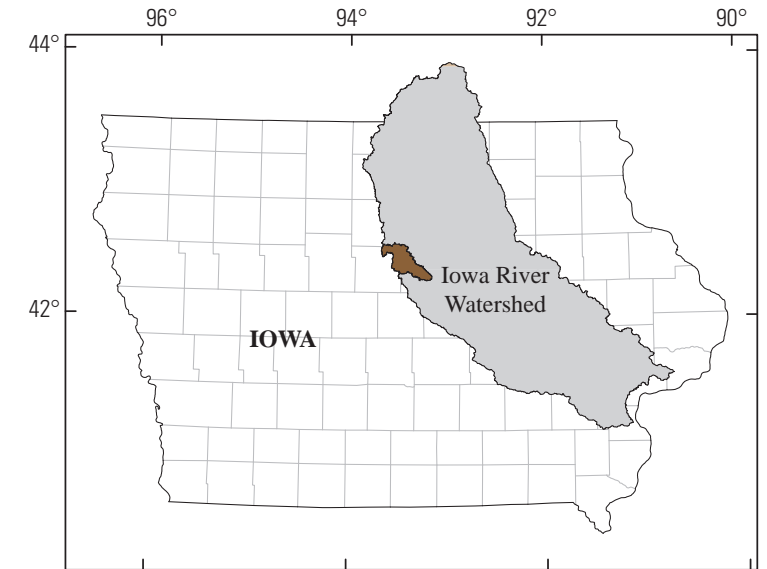

$90^{\circ}$
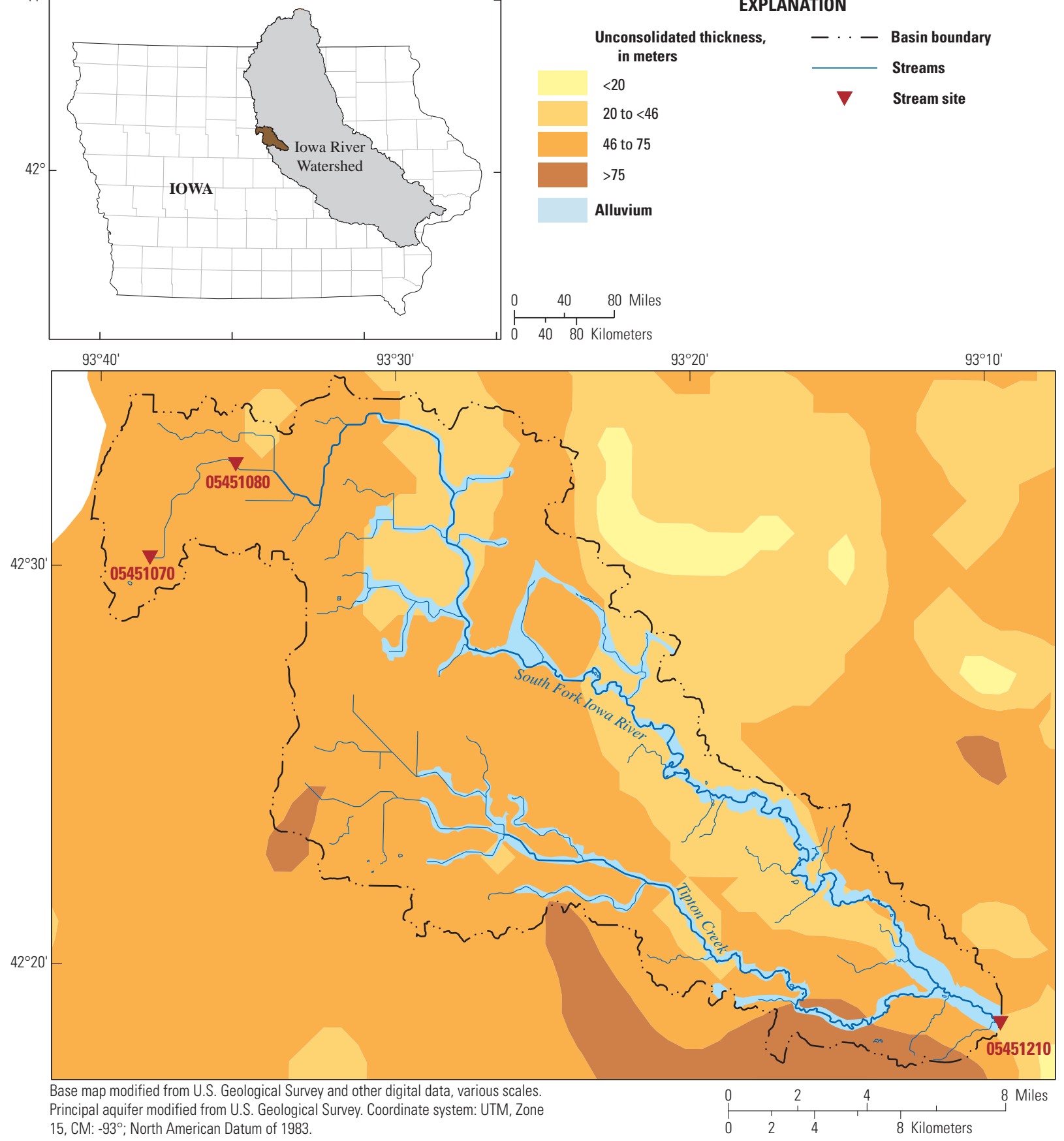

Figure 8. Thickness of unconsolidated material and the location of alluvial deposits in the South Fork lowa River basin. 
Floods in the South Fork Iowa River generally are caused by spring rains on frozen or saturated soils, by heavy summer thunderstorms, and by fall rains after harvest. The worst recorded flood in the study basin, with an estimated occurrence probability of between 0.2 and 1 percent in the headwaters catchment to between 2 and 4 percent in the South Fork Iowa River basin, occurred in June 2008 (Buchmiller and Eash, 2010). Periodic droughts in central Iowa have lasted from weeks to years. The lack of water during droughts negatively affects the human population, livestock, and agriculture. The worst recorded drought in north-central Iowa - with a recurrence interval of 25 to 60 years - extended from 1933 through 1936. The smallest 7-day minimum streamflow recorded at site 05451210 was $0.05 \mathrm{~m}^{3} / \mathrm{s}$, and occurred during September 2000 (U.S. Geological Survey, 2001).

The site 05451070 catchment, nested within the site 05451080 catchment, has an estimated area of $7.0 \mathrm{~km}^{2}$ (fig. 3). The area of the catchment is estimated because the extent of the subsurface drainage network in unknown. Subsurface drainage accounts for most of the flow at site 05451070 . This flow is a combination of water that has infiltrated the soil and subsequently moved to horizontal drains and water that has entered the drains through vertical inlets in fields and roadway ditches. Overland flow contributes water directly to the stream only during extremely intense rain events.

Site 423135093373301 (fig. 4) is $3.2 \mathrm{~km}$ downstream of site 05451070 . This site is situated at the edge of the stream that receives surface runoff (overland flow) from a 90-ha catchment. Runoff from light to moderate rains from the western two-thirds of this small catchment flows into the South Fork Iowa River through subsurface drains. Runoff from the eastern one-third of this small catchment flows overland and enters the South Fork Iowa River through a $0.46 \mathrm{~m}$ culvert installed in the streambank. During extreme rain events, when subsurface drain capacity is exceeded, water can flow overland from the entire 90-ha catchment into the streambank culvert.

Site 05451080 is located about $7.6 \mathrm{~km}$ downstream of site 05451070 (fig. 4). The catchment for this site has an area of $31 \mathrm{~km}^{2}$. Flow at site 05451080 is a mixture of water from precipitation, subsurface drains, groundwater discharge, and overland flow.
Two subsurface drains were included in a focus study (fig. 4). The outflow of one drain (423232093351801, site TD-2, 20-cm diameter) is located on the western side of the stream, approximately $0.19 \mathrm{~km}$ downstream of site 05451080 . The outflow of the second drain (423230093351501, site TD-3, 40-cm diameter) is located on the western side of the stream, approximately $0.26 \mathrm{~km}$ downstream of site 05451080 . The locations and extents of the subsurface drain networks associated with these two drain outflows are partially unknown, but generally the subsurface drains were installed in the topographically low areas. The area drained through site TD-2 may be from 20 to 25 ha. The area drained by TD-3 may be twice as large - greater than 50 ha. The subsurface drains discharging at TD-3 has at least one vertical inlet in a nearby field.

\section{Data Collection}

At site 05451210 , water samples were collected monthly to weekly from 2006 to 2009. A continuous water-quality monitor measured temperature, specific conductance, $\mathrm{pH}$, and dissolved oxygen during ice-free periods from April into November.

Continuous streamflow at site 05451070 was estimated from stage from October 2007 through November 2008. Water-quality data were obtained from samples collected approximately monthly during the winter and early spring and weekly during the late spring and summer 2007 and monthly in 2008.

Stream stage was recorded continuously from 2006 to 2009 at a gaging station at site 05451080 . Water samples at this site were collected monthly to weekly from 2006 to 2009. Supplemental samples were collected periodically during storm events by an autosampler triggered by rising stream levels. A continuous water-quality monitor measured temperature, specific conductance, $\mathrm{pH}$, and dissolved oxygen during ice-free periods from April into November.

At site 423135093373301, flow was measured in the streambank culvert with a stage discharge relation and with an acoustic flow meter. Water samples were collected manually and with an autosampler triggered by rising water levels. The water temperature and specific conductance of the runoff was measured with a continuous water-quality monitor. Flow and water-quality data were collected at this site from April through September 2008. 


\section{Environmental Settings of South Fork lowa River Basin, lowa, and Bogue Phalia Basin, Mississippi, 2006-10}

For both subsurface drains (sites TD-2 and TD-3; fig. 4), discharge measurements were made with an acoustic flow meter. Water-quality samples were manually collected periodically and storm samples were collected by an autosampler triggered by decreasing specific conductance values that are indicative of increasing subsurface flow after the onset of rain. Continuous water-quality monitors measured temperature and specific conductance of the subsurface discharge.

Near the outlet from the headwaters catchment (fig. 5), data were collected from nests of suction lysimeters, soil-moisture probes, and shallow wells that were installed in transects. The transects were perpendicular to one of the subsurface drains and roughly parallel to the channel of the South Fork Iowa River. One transect was located in the cropped field about $65 \mathrm{~m}$ from the stream and the other was located in a grassy buffer strip about $30 \mathrm{~m}$ from the stream. The lysimeters were placed about $0.91 \mathrm{~m}$ below land surface to collect water samples in the unsaturated zone. The soil moisture probes were located at approximately 0.3 and $0.6 \mathrm{~m}$ below land surface to measure soil moisture. Wells were located at approximately $1.2,3.0$, and $4.3 \mathrm{~m}$ below land surface to monitor water levels and the water quality of the saturated zone.

Rain samples were collected weekly for analysis of selected pesticides at site PPT-1, just west of site 05451080 (fig. 4). Samples were collected in 2007 and 2008 from April through September using a modified automatic wet-dry precipitation collector. Collected rainwater was funneled into a glass carboy inside a small refrigeration unit located beneath the deposition collector. Refrigeration was used to help minimize evaporative losses of the water and to reduce volatilization losses and biotic and abiotic degradation of the nutrients and pesticides during the sample collection period. Samples were a composite of precipitation events that occurred during a 7-day period. Weekly air samples for selected pesticides and total suspended particulates were collected with calibrated vacuum air samplers that integrated over the 7-day period of collection.
At the downstream focus study area near the basin outlet, streambed temperatures were measured at two depths in a 450-m reach of the South Fork Iowa River upstream of site 05451210 in the summer of 2007 and 2008 to map areas where groundwater was seeping into the river or stream water was moving into the underlying aquifer. Streambed temperatures were measured at shallow $(15 \mathrm{~cm})$ and deep $(50 \mathrm{~cm})$ points at $3-\mathrm{m}$ increments at 40 cross sections in the stream (fig. 9). Cool temperatures in the streambed-similar to those in the shallow alluvial aquifer-were inferred to mean that water was moving from the aquifer to the stream and warm streambed temperatures were inferred to mean that either stream water was present or there was no movement of water between aquifer and stream. To better understand temporal changes in movement of water between the river and alluvial aquifer, continuous monitors were used to measure water temperature and specific conductance in a streamside piezometer for comparison with water temperature and specific conductance in the South Fork Iowa River. Water temperature and specific conductance in water about a meter below the streambed was measured continuously from May 2008 through March 2009 at piezometer TR1-1A at the edge of the river about $160 \mathrm{~m}$ upstream of the New Providence gage.

Just upstream of the basin outlet (fig. 3), detailed data were collected at several locations in 2007 and 2008 in and near the stream. Temporary drive-point piezometers were installed to collect subsurface water samples and measure the hydraulic gradient between the stream and the subsurface. Each location consisted of a three by three array of piezometers, generally located $2 \mathrm{~m}$ apart. Multiple arrays were measured to document any differences due to stream conditions. Arrays were located in a straight reach (TR1), a riffle (TR2), an inside bend (TR3), and an outside bend (TR4) of the river. The hydraulic gradient and water samples were collected from $0.3,0.5$, and $1.0 \mathrm{~m}$ below the sediment-water interface in the channel. 

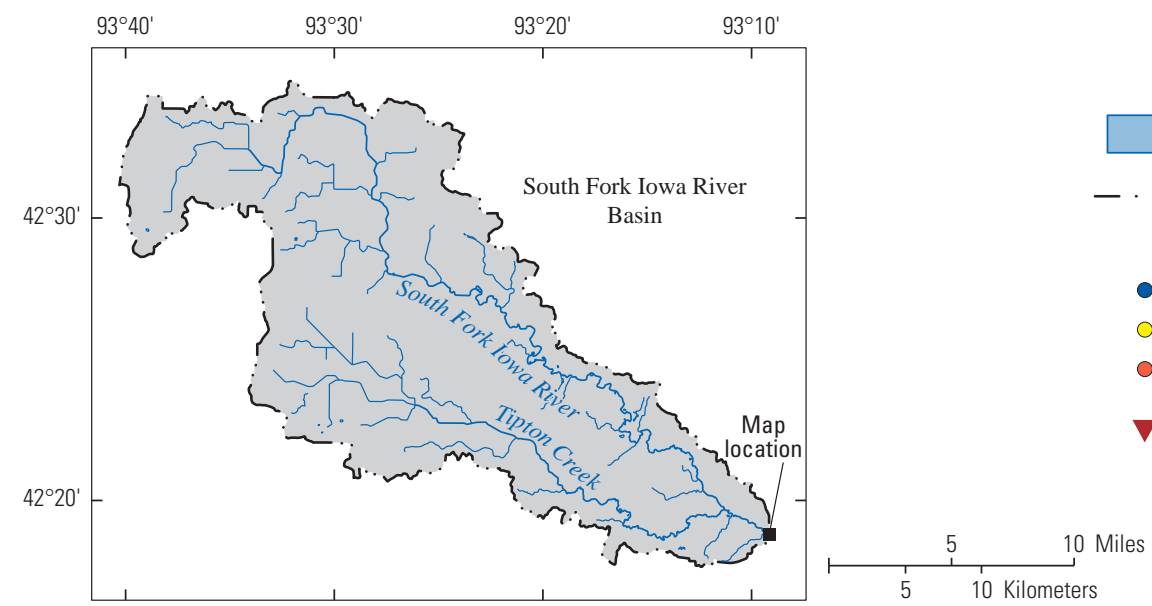

\section{EXPLANATION}

Streambed 2007

Basin boundary

Streambed temperature

0.0 to $15.0^{\circ} \mathrm{C}$

Greater than 15 to $18.0^{\circ} \mathrm{C}$

Greater than $18.0^{\circ} \mathrm{C}$

Stream site

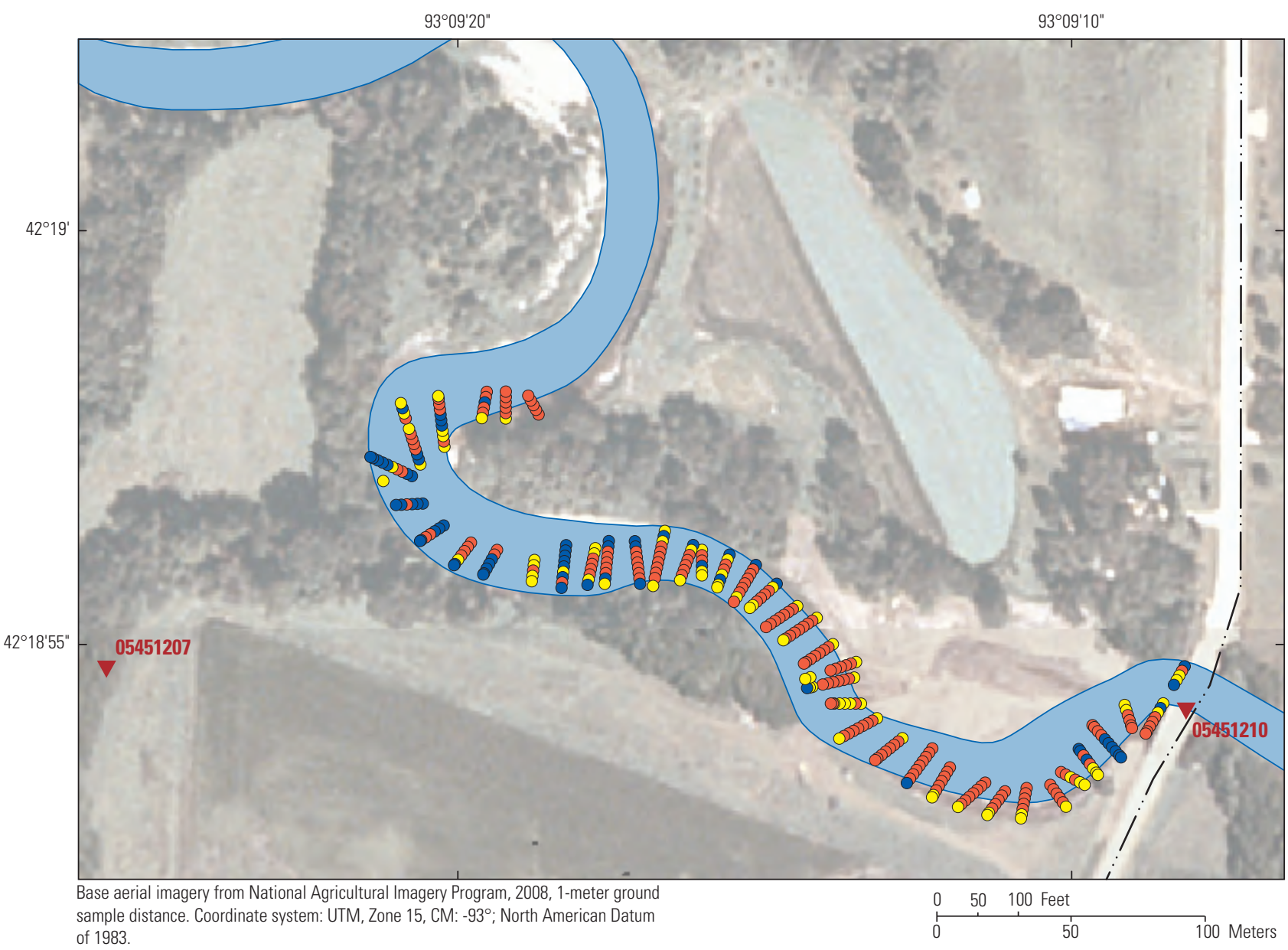

Figure 9. Streambed temperatures near the outflow from the South Fork lowa River basin, 2008. 


\section{Bogue Phalia Basin Study Area}

In the Bogue Phalia basin (fig. 10), data for the ACT study were collected during water years $2006-10$ from surface water, groundwater, the unsaturated zone, the streambed, and precipitation (table 2). Surface-water data were collected from several sites (fig. 11), including the outflows from the Bogue Phalia basin (site 07288650), and two catchments within the basin where focused studies were conducted-the Tommie Bayou catchment (site 07288636), and the catchment of an unnamed tributary to Clear Creek (site 333150090530400). Groundwater and unsaturated-zone data were collected from a focused study area near the basin headwaters (fig. 11B) to assess areal groundwater recharge and better understand the fluxes of water and chemicals to the underlying alluvial aquifer. Streambed and related data were collected from another focused area just upstream of the basin outlet (fig. 11C) to assess the hydrologic and chemical interactions between surface water and groundwater and to determine the direction of local groundwater flow. Precipitation data were collected at two sites in the Tommie Bayou catchment (fig. 11A) to determine the intensity and timing of rainfall, and atmospheric samples were collected at one of these sites to measure pesticides in air and rain.

\section{Environmental Setting}

The Bogue Phalia basin covers $1,250 \mathrm{~km}^{2}$ within the Yazoo River basin in northwestern Mississippi (ig. 10). The area is locally referred to as the "Delta." The region has a moderate climate with temperatures ranging from a mean of $26^{\circ} \mathrm{C}$ in July to a mean of $5^{\circ} \mathrm{C}$ in January. Mean annual precipitation for the 13-year period of record (1996-2008) was $137 \mathrm{~cm}$. Typically, less than 30 percent of the annual precipitation occurs during the May-August growing season (fig. 12). Evapotranspiration plays a large role in the water budget of this area, with an annual average of 120 to $149 \mathrm{~cm}$ of moisture returning to the atmosphere as a result of evaporation and transpiration. (Air temperature, precipitation, and evapotranspiration information presented here is based on data collected and archived by the Mississippi State University Extension Service, Stoneville station, 2011.)

\section{Land Use}

Agriculture is the principal land use in the Bogue Phalia basin, and 80 percent of the total land area is used for row crops including corn, soybeans, rice, and cotton. Growers in the area use a broad variety of fertilizers, herbicides, and pesticides, but manure application is uncommon. The uneven distribution of precipitation throughout the year (fig. 12) makes irrigation a necessity for profitable agriculture, and because of the flat topography and generally poorly drained soils, successful farming in the area typically requires some type of engineered drainage.

The study area is sparsely populated (less than 15 persons $/ \mathrm{km}^{2}$ ) and residents live either in small communities or rural areas. The combined population of Bolivar, Carroll, Coahoma, Grenada, Holmes, Humphreys, Issaquena, Leflore, Panola, Quitman, Sharkey, Sunflower, Tallahatchie, Tunica, Warren, Washington, and Yazoo Counties - an area of more than $26,000 \mathrm{~km}^{2}$-is less than 400,000 .

\section{Physiography, Geology, and Soils}

Physiographically, the Bogue Phalia basin is completely contained within the Mississippi River Alluvial Plain, an area that was the Mississippi River flood plain before levees were built. The Bogue Phalia basin overlies quaternaryage, unconsolidated alluvial materials (sand and gravel), which were deposited on an erosional surface composed of Tertiary-age sand and clay units.

The primary aquifer of interest underlying the Bogue Phalia basin is the Mississippi River Valley alluvial aquifer, often referred to simply as the "alluvial aquifer" (fig. 10). The alluvial aquifer is the primary source of groundwater for irrigation, but generally is not used for drinking water due to issues with encrustation, color, and taste associated with hardness and high iron content (Taylor and Thompson, 1971).

Soil types in the Bogue Phalia basin are broadly identified as the Forestdale, Sharkey, Alligator, Dundee, and Commerce series, which range from a very fine smectitic clay to a fine, silty loam, respectively. Soils generally are shallow, very poorly to somewhat poorly drained, finely textured, and nearly level. Erosion from runoff occurs, but it is not a major issue as the slope of the land generally is very low (from 0 to 8 percent) and deep-tillage is no longer practiced regularly in the area. Available water capacity of the soils varies from very low to moderately high, and the organic matter content is moderate. The Forestdale, Sharkey, and Alligator series soils are naturally suited to row crops, such as rice and soybeans, although the Dundee and Commerce series soils are naturally suited to row crops, such as corn and cotton. 


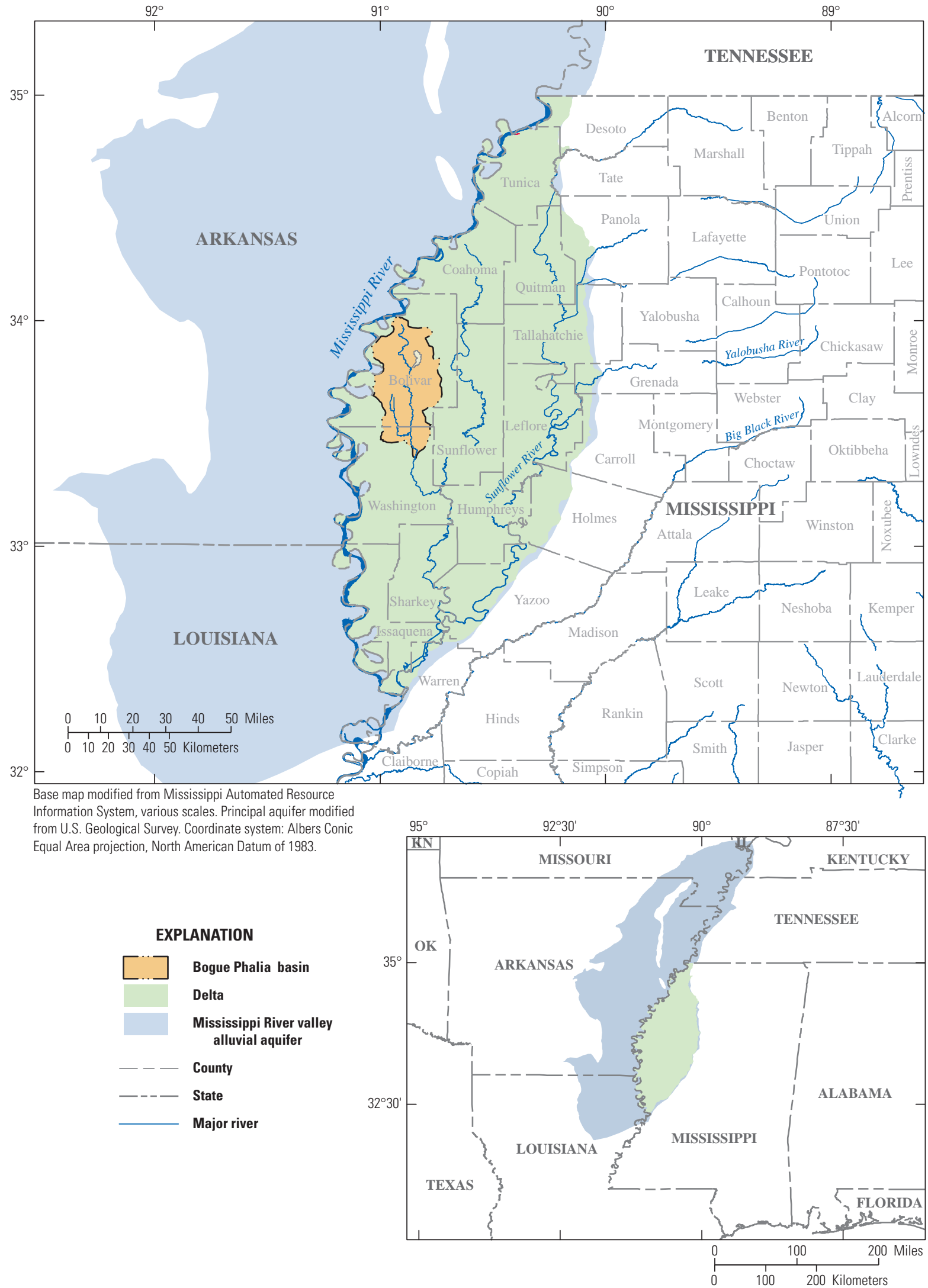

Figure 10. Bogue Phalia basin. 


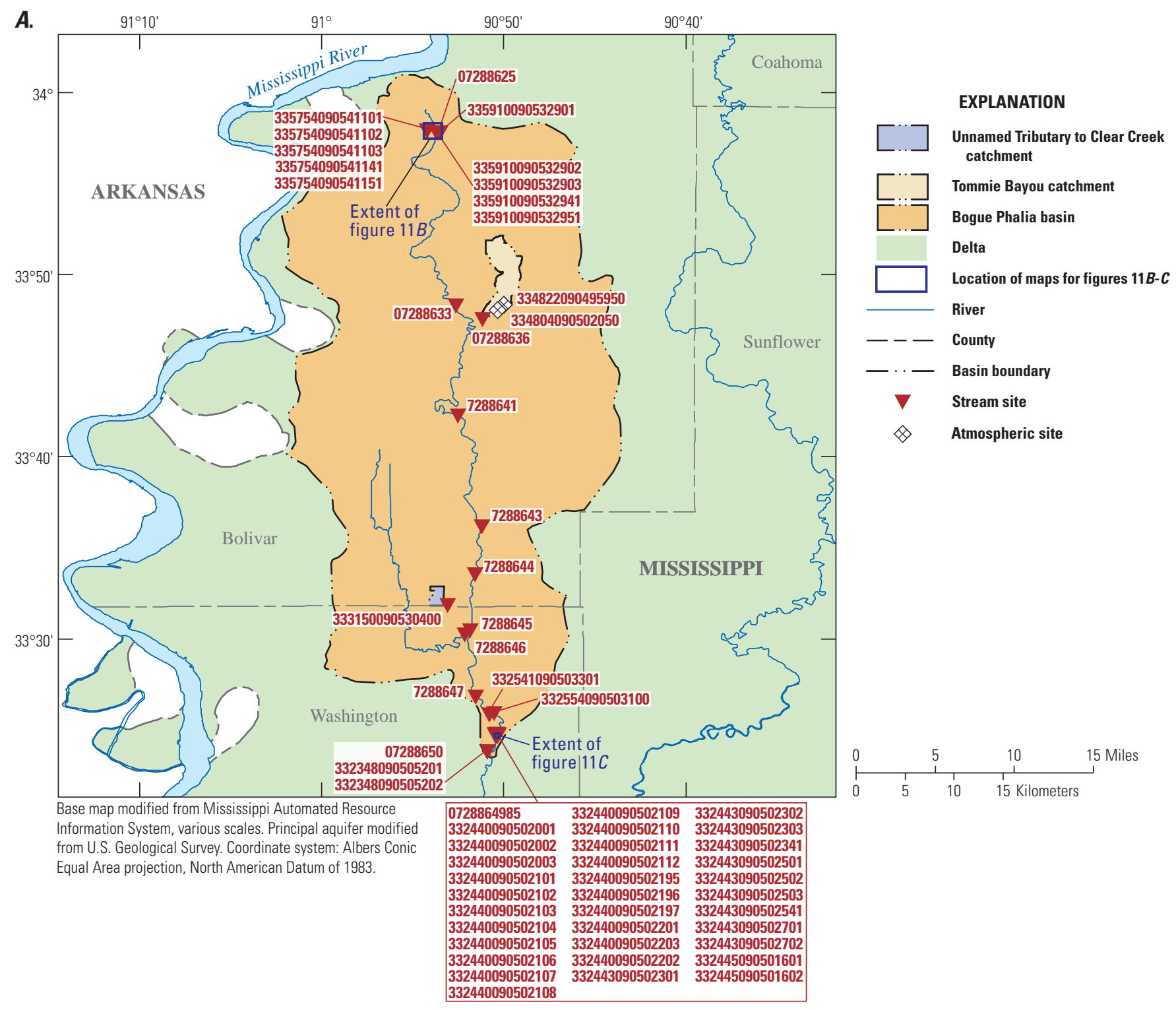

Figure 11. Locations of data-collection sites in the $(A)$ Bogue Phalia basin, $(B)$ headwaters focused study area, and $(C)$ basin outlet focused study area.

\section{Hydrology}

The average discharge at the surface-water outflow of the Bogue Phalia basin is $21.3 \mathrm{~m}^{3} / \mathrm{s}$ and ranges between 0.10 and $274 \mathrm{~m}^{3} / \mathrm{s}$ (U.S. Geological Survey, 2010, site 07288650). This discharge is from a combination of overland flow from precipitation, irrigation runoff, and - to a much lesser extentsubsurface drainage and groundwater discharge. Floods in the Bogue Phalia basin can be caused by heavy rains within the basin (including rain associated with nearby hurricanes), as well as rainfall events outside of the basin. For example, flooding in upstream basins can lead to flooding in the Delta reach of the Mississippi River that can breech levees and cause flooding in the Bogue Phalia basin. In fact, the worst recorded flood in the study basin, with an estimated occurrence interval exceeding 100 years, occurred in 1927 as the result of rainfall events in the Midwest. Major floods, such as those brought on by hurricane events can occur even during droughts. At base flow, the Bogue Phalia primarily contains drainage water from bank storage and discharge from shallow groundwater, and some reaches can become dry during the summer and fall. The record 7-day minimum streamflow recorded at the basin outlet (site 07288650 ) was $4.20 \mathrm{~m}^{3} / \mathrm{s}$ in early November 2007. 


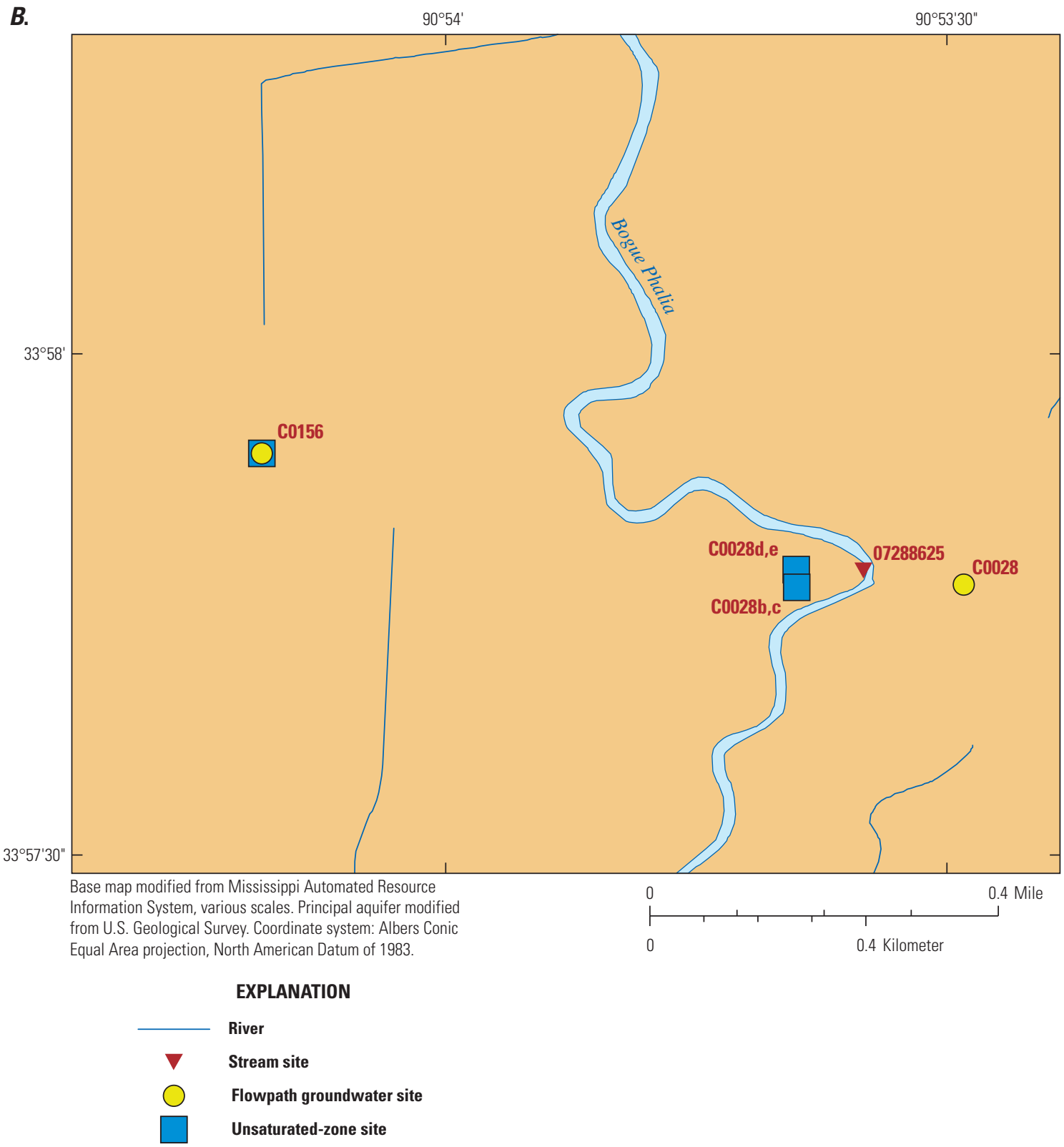

Figure 11.-Continued

Major modifications, such as the building of levees, deforestation, and the draining of wetlands have been made to the natural hydrology of the Bogue Phalia basin to promote agriculture. Installation of irrigation wells also has had a major effect on the hydrology of the basin. The amount of water typically pumped from the alluvial aquifer in Mississippi alone is approximately 3.9 billion gal/d during the growing season
(Maupin and Barber, 2005). Many Delta streams have lost connection with the shallow alluvial aquifer due to declines in the water table from the high irrigation withdrawal rates. In 2005, a large number of irrigation wells were installed to pump water into the Big Sunflower River (to which the Bogue Phalia is a tributary) to supplement flow that had declined markedly as a result of irrigation. 


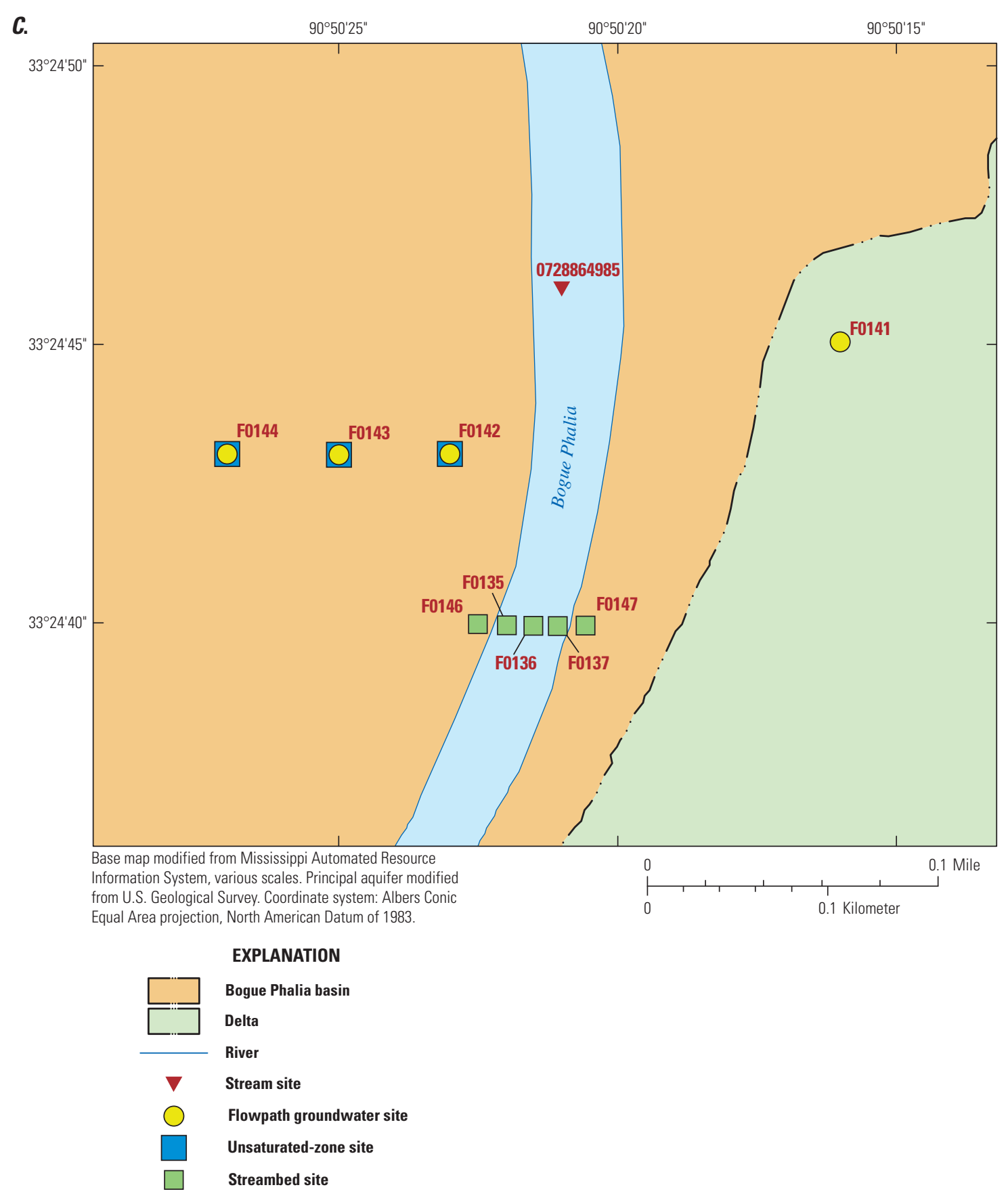

Figure 11.-Continued

Sites 07288636 and 333150090530400 (ig. 11A) are located at the surface-water outflows of the two focus catchments. More than 90 percent of the land in both of these catchments is used for row crops, and surface-water outflow from both is comprised primarily of overland flow. The Tommie Bayou at site 07288636, located $44.8 \mathrm{~km}$ upstream of site 07288650 , has a drainage area of $15.3 \mathrm{~km}^{2}$. The observed range of flow at the site is 0.0 to $25.0 \mathrm{~m}^{3} / \mathrm{s}$, and the average annual discharge is $0.18 \mathrm{~m}^{3} / \mathrm{s}$. Elevated discharge at site 07288636 is often due to the release of water from rice fields within the catchment; however, during the dry season and in the absence of overland runoff, the stream can become stagnant. Site 333150090530400 , located $16.3 \mathrm{~km}$ upstream of site 07288650 , drains an area of $2.2 \mathrm{~km}^{2}$. Observed flow at the site ranges from 0.0 to $2.4 \mathrm{~m}^{3} / \mathrm{s}$, and the average annual discharge is $0.06 \mathrm{~m}^{3} / \mathrm{s}$. The stream at site 333150090530400 is dry much of the time. 


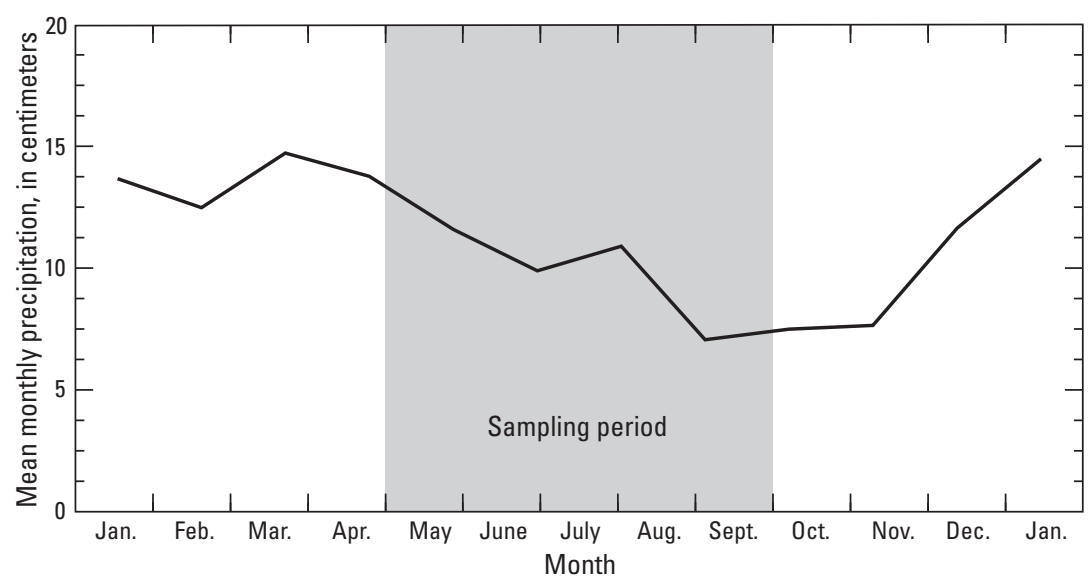

Figure 12. Mean monthly precipitation at the Mississippi atmospheric sampling sites. Data are from National Oceanic and Atmospheric Administration (2002b) 1931-2000 average for Mississippi climatic region 4.

\section{Data Collection}

For site 07288650 , flow data were available from the USGS gaging station, and water samples for chemical analyses were collected 67 times during the 2006-10 study period, including during both base flow and storm conditions. In addition to samples for chemical analyses, which were collected manually, a continuous water-quality monitor measured temperature and specific conductance. Two additional continuous temperature and specific conductance monitoring probes were installed in streambed piezometers at a depths of 1 and $2 \mathrm{~m}$ near site 07288650 .

Flow at site 07288636 was determined by discharge measurements made with an acoustic flow sensor. Collection of water samples occurred during both base flow and storm conditions. Base flow samples were collected manually, and storm samples were collected when an autosampler was triggered by rising stage in the stream. A continuous waterquality monitor measured temperature, specific conductance, $\mathrm{pH}$, and dissolved oxygen. This site also was equipped with a precipitation gage and with samplers for the collection of pesticides in air and rain.

Flow at site 333150090530400 was estimated from stage. For the time period between October 1, 2006, and October 10, 2007 , two culverts were installed below the gage to direct flow under a road. From October 11, 2007, through November 6, 2007, there were no culverts at the site. On November 7, 2007, a single, larger culvert was installed below the gage to replace the two, smaller culverts. Infrequent water samples were manually collected during base flow and storms. Storm samples were collected by an autosampler triggered by rising stage in the stream. A continuous water-quality monitor measured temperature, specific conductance, and $\mathrm{pH}$. A precipitation gage was maintained at this site.

To assess the quality of groundwater in the alluvial aquifer at the areal recharge study area (fig. 11A), which had relatively permeable soils, water samples were collected and analyzed for various chemical constituents from a shallow (10 m deep) water-table well and an abandoned irrigation well (36.6 $\mathrm{m}$ deep). The two wells were sampled nine times from 2006 to 2008 for major ion chemistry, nutrients, and field parameters (depth to water, $\mathrm{pH}$, water temperature, specific conductance, dissolved oxygen, and turbidity). Soil moisture probes also were installed at the site.

At the groundwater/surface-water interaction and flow system study area (fig. 11B), 13 locations in and near the stream were sampled to assess the hydraulic gradient between the stream and the subsurface using installed drive-point samplers and piezometers. Samples were collected from $2 \mathrm{~m}$ below the sediment-water interface in the channel, and from 9.8 to $12.2 \mathrm{~m}$ below land surface on the eastern and western sides of the channel. All piezometers were instrumented with pressure transducers, which measured groundwater level and temperature at 15-minute intervals. Temperature dataloggers were installed at fixed depths within the in-stream piezometers and recorded water temperature every 15 minutes. Water level and temperature were recorded continuously in four nearstream piezometers, five piezometers in the streambed, and surface water. Nests of soil-moisture probes and shallow wells also were installed adjacent to the stream to determine water quality and the direction of local groundwater flow in the alluvial aquifer. 


\section{References Cited}

Barlow, J.R., and Coupe, R.H., 2009, Use of heat to estimate streambed fluxes during extreme hydrologic events: Water Resources Research, v. 45, W01403, doi:10.1029/2007WR006121, accessed October 24, 2011, at http://www.agu.org/pubs/crossref/2009/2007WR006121. shtml.

Becher, K.D., Kalkhoff, S.J., Schnoebelen, D.J., Barnes, K.K., and Miller, V.E., 2001, Water-quality assessment of the Eastern Iowa Basins-Nitrogen, phosphorus, suspended sediment, and organic carbon in surface water, 1996-98: U.S. Geological Survey Water-Resources Investigations Report 01-4175, 56 p. (Also available at http://pubs.usgs. gov/wri/wri014175/.)

Buchmiller, R.C., and Eash, D.A., 2010, Floods of May and June 2008 in Iowa: U.S. Geological Survey Open-File Report 2010-1096, 10 p. (Also available at http://pubs.usgs. gov/of/2010/1096/.)

Capel, P.D., McCarthy, K.A., and Barbash, J.E., 2008, National, holistic, watershed-scale approach to understand the sources, transport, and fate of agricultural chemicals: Journal of Environmental Quality, v. 37, no. 3, p. 983-993.

Coupe, R.H., 2000, Occurrence of pesticides in five rivers of the Mississippi Embayment Study Unit, 1996-98: U.S. Geological Survey Water-Resources Investigations Report 99-4159, 55 p. (Also available at http://pubs.er.usgs.gov/ publication/wri994159.)

Coupe, R.H., 2002, Nitrogen and phosphorus concentrations and fluxes of streams in the Mississippi Embayment Study Unit, 1996-98: U.S. Geological Survey Water-Resources Investigations Report 01-4024, 65 p.

Coupe, R.H., 2007, Use of a watershed model to characterize the fate and transport of fluometuron, a soil-applied cotton herbicide, in surface water: Intern Journal of Environmental and Analytical Chemistry, v. 87, no. 13, p. 883-896.

Coupe, R.H., Manning, M.A., Foreman, W.T., Goolsby, D.A., and Majewski, M.S., 2000, Occurrence of pesticides in rain and air in urban and agricultural areas of Mississippi, AprilSeptember 1995: The Science of the Total Environment, v. 248 , no. $2-3$, p. 227-240.

Coupe, R.H., Thurman, E.M., and Zimmerman, L.R., 1998, Relation of usage to the occurrence of cotton and rice herbicides in three streams of the Mississippi Delta: Environmental Science and Technology, v. 32, no. 23, p. 3673-3680.
Coupe, R.H., Welch, H.L, Pell, A.B., and Thurman, E.M., 2005, Herbicide and degradate flux in the Yazoo River Basin: International Journal of Environmental and Analytical Chemistry, v. 85, no. 15, p. 1127-1140.

Foreman, W.T., Majewski, M.S., Goolsby, D.A., Wiebe, F.W., and Coupe, R.H., 2000, Pesticides in the atmosphere of the Mississippi River Valley, part II-air: The Science of the Total Environment, v. 248, no. 2-3, p. 213-226.

Kalkhoff, S.J., Barnes, K.K., Becher, K.D., Savoca, M.E., Schnoebelen, D.J., Sadorf, E.M., Porter, S.D., and Sullivan, D.J., 2001, Water quality in the Eastern Iowa basins, Iowa and Minnesota, 1996-98: U.S. Geological Survey Circular 1210, 37 p. (Also available at http://pubs.usgs.gov/circ/ circ1210/.)

Kalkhoff, S.J., Lee, K.E., Porter, S.D., Terrio, P.J., and Thurman, E.M., 2003, Herbicides and herbicide degradation products in upper Midwest agricultural streams during August base-flow conditions: Journal of Environmental Quality, v. 32, p. 1025-1035.

Kleiss, B.A., Coupe, R.H., Gonthier, G.J., and Justus, B.G., 2000, Water quality in the Mississippi Embayment, Mississippi, Louisiana, Arkansas, Missouri, Tennessee, and Kentucky, 1995-98: U.S. Geological Survey Circular 1208, 36 p. (Also available at http://pubs.usgs.gov/circ/circ1208/.)

Maupin, M.A., and Barber, N.L., 2005, Estimated withdrawals from the principal aquifers in the United States, 2000: U.S. Geological Survey Circular 1279, 46 p. (Also available at http://pubs.usgs.gov/circ/2005/1279/.)

McCarthy, K.A., Lampe, D.C., and Capel, P.D., 2011, Discrete and continuous water-quality data and hydrologic parameters from seven agricultural watersheds in the United States, 2002-09: U.S. Geological Survey Data Series 603, 10 p. (Also available at http://pubs.usgs.gov/ds/603/.)

Mississippi State University Extension Service, 2011, Stoneville station, database: accessed December 16, 2011, at http://ext.msstate.edu/anr/drec/weather.cgi.

National Oceanic and Atmospheric Administration, 2002a, Divisional normals and standard deviations of temperature, precipitation, and heating and cooling degree days 19712000-Section 1-Temperature: National Oceanic and Atmospheric Administration Climatography of the United States, no. 85, 69 p. accessed October 24, 2011, at http:// cdo.ncdc.noaa.gov/climatenormals/clim85/CLIM85 TEMP01.pdf. 
National Oceanic and Atmospheric Administration, 2002b, Divisional Normals and Standard Deviations of Temperature, Precipitation, and Heating and Cooling Degree Days 1971-2000-Section 2-Precipitation: National Oceanic and Atmospheric Administration Climatography of the United States, no. 85, 71 p., accessed October 24, 2011, at http://cdo.ncdc.noaa.gov/ climatenormals/clim85/CLIM85 PRCP02.pdf.

Olcott, P.G., 1992, Ground water atlas of the United States, Iowa, Michigan, Minnesota, Wisconsin: U.S. Geological Survey Hydrologic Investigations Atlas 730-J, 31 p., accessed October 24, 2011, at http://mi.water.usgs.gov/ pubs/HA/HA730-J/.

Porter, S.D., Harris, M.A., and Kalkhoff, S.J., 2001, Influence of natural factors on the quality of Midwestern streams and rivers: U.S. Geological Survey Water-Resources Investigations Report 00-4288, 13 p. (Also available at http://pubs.usgs.gov/wri/wri004288/.)

Quade, D.J., and Giglierona, J.D., 2006, Surficial geologic map of the Des Moines Lobe of Iowa Phase 8-Hardin County: Iowa Geological Survey Open-File Map OFM-06-6, 1 sheet.

Quade, D.J., Giglierona, J.D., Bettis, E.A., and Wisner, R.J., 2000, Surficial geologic map of the Des Moines Lobe of Iowa Hamilton and Webster Counties: Iowa Geological Survey Bureau Open-File Map 2000-1, 1 sheet.

Runner, M.S., Turnipseed, D.P., and Coupe, R.H., 2002, Stream flow and nutrient data for the Yazoo River below Steele Bayou near Long Lake, Mississippi, 1996-2000: U.S. Geological Survey Water-Resources Investigations Report 02-4215, 35 p. (Also available at http://ms.water.usgs.gov/ publications/WRIR_02_4215.html.)

Schnoebelen, D.J., Kalkhoff, S.J., Becher, K.D., and Thurman, E.M., 2003, Water-quality assessment of the Eastern Iowa Basins-Selected pesticides and pesticide degradates in steams, 1996-98: U.S. Geological Survey Water-Resources Investigations Report 03-4075, 62 p. (Also available at http://pubs.usgs.gov/wri/2003/wri034075/.)

Taylor, R.E., and Thompson, F.H., 1971, Water for industry and agriculture in Washington County, Mississippi. Prepared by USGS Water Resources Division, published by Delta Council, Stoneville, Mississippi, 64 p.

Tomer, M.D., Moorman, T.B., and Rossi, C.G., 2008a, Assessment of the Iowa River's South Fork watershedPart 1, Water quality: Journal of Soil and Water Conservation, v. 63, no. 6, p. 360-370.
Tomer, M.D., Moorman, T.B., James, D.E., Hadish, G., and Rossi, C.G., 2008b, Assessment of the Iowa River's South Fork watershed-Part 2, Conservation practices: Journal of Soil and Water Conservation, v. 63, no. 6, p. 371-379.

U.S. Census Bureau, 2000a, Census 2000 Block Maps: U.S. Census Bureau, accessed October 24, 2011, at http://ftp2. census.gov/geo/maps/blk2000/st19 Iowa/.

U.S. Census Bureau, 2000b, Census 2000 Data for the State of Iowa: U.S. Census Bureau, accessed October 24, 2011, at http://www.census.gov/census2000/states/ia.html.

U.S. Department of Agriculture, 2009, The Census of Agriculture: National Agricultural Statistics Service, accessed October 24, 2011, at http://www.agcensus.usda. gov/index.asp.

U.S. Geological Survey, 2001, U.S. Geological Survey National Water Information System (NWISWeb): U.S. Geological Survey, accessed August 31, 2010, at http:// waterdata.usgs.gov/nwis/sw.

U.S. Geological Survey, 2008, Water-resources data for the United States, water year 2007: U.S. Geological Survey Water Data Report WDR-US-2007, accessed October 24, 2011, at http://wdr.water.usgs.gov/.

U.S. Geological Survey, 2009, Water-resources data for the United States, water year 2008: U.S. Geological Survey Water-Data Report WDR-US-2008, accessed October 24, 2011, at http://wdr.water.usgs.gov/.

U.S. Geological Survey, 2010, Water-resources data for the United States, water year 2009: U.S. Geological Survey Water Data Report WDR-US-2008, accessed October 24, 2011, at http://wdr.water.usgs.gov/.

U.S. Geological Survey, 2011, National Water-Quality Assessment Program publications: website, accessed December 16, 2011, at http://water.usgs.gov/nawqa/bib/.

Welch, H.L., Green, C.T., and Coupe, R.H., 2011, The fate and transport of nitrate in shallow groundwater in northwestern Mississippi, USA: Hydrogeology Journal, 14 p., online in advance of print, doi: 10.1007/s10040-011-0748-8, accessed October 24, 2011, at http://www.springerlink.com/ content/235p7gqmg2u2q556/. 
The tables for the data-collection sites are in Excel format and are available to download at http://pubs.usgs.gov/ $\underline{\text { sir/2012/5021/. }}$

Table 1. Data collection sites in the South Fork lowa River basin, water years 2006-09.

Table 2. Data collection sites in the Bogue Phalia basin, water years 2006-10. 
Publishing support provided by the U.S. Geological Survey

Publishing Network, Tacoma Publishing Service Center

For more information concerning the research in this report, contact the Director, Oregon Water Science Center

U.S. Geological Survey

2130 SW 5th Avenue

Portland, Oregon 97201

http://or.water.usgs.gov 
